\title{
The Skills of the Unskilled in the American Industrial Revolution
}

\author{
By James Bessen*
}

$2 / 02$

\begin{abstract}
Were ordinary factory workers unskilled and was technology "de-skilling" during the Industrial Revolution? I measure foregone output to estimate the human capital investments in mule spinners and power loom tenders in ante-bellum Lowell. These investments rivaled those of craft apprentices. Although factory workers were unskilled in a sense, the implementation of this technology depended on the development of a labor force with substantial human capital. From 1834-55, firms made increasing investments in skill, allowing workers to tend more machines, thus raising labor productivity. This growing investment was motivated partly by changing factor prices and more by a changing labor supply. Calculations show that firm policy and social conditions, including literacy, influenced the investment in factory skills. When skills are considered, technological change at Lowell appears as a broad social process, dependent as much on innovation in institutions as on invention of machines.
\end{abstract}

Keywords: Industrial Revolution, technological change, learning-by-doing, growth, human capital

JEL codes: O30, N61, J24

\author{
James Bessen \\ Research on Innovation \\ jbessen@researchoninnovation.org
}

\footnotetext{
* Thanks to Bob Hunt, David Landes, Tim Leunig, John Lyons, Bob Margo, David Mitch, John Murray and participants at the Economic History Association and seminars at the Federal Reserve Bank of Philadelphia and University of Maryland, Baltimore County. Many thanks also to Tom Brush, Margaretha Hendrickx and William Lazonick for their patient assistance in providing data. This research was supported by Research on Innovation.
} 


\section{Introduction}

David Landes [1969, pg. 1] succinctly summarizes the de-skilling hypothesis for the Industrial Revolution: new technology brought about "a substitution of mechanical devices for human skills" and "inanimate power-in particular, steam—-took the place of human and animal strength." By several measures, ordinary factory workers were unskilled. Compared to workers in craft and professional occupations, factory workers earned lower wages. Also, factory jobs did not require formal education, training periods were brief, factory work was monotonous and factory workers lacked both social status and market power. Thus a wide body of evidence supports deskilling as a description of the change in the nature of the labor supply.

But the de-skilling hypothesis is also about technology. De-skilling technology implies that no significant investment in developing the skills of ordinary workers was required. Although millwrights and engineers needed new skills, the hypothesis implies that ordinary workers' skills imposed no significant requirements on the adoption and implementation of this new technology. Technological change appears as an elite process, driven by inventors, entrepreneurs and a narrow stratum of supporting skilled craftsmen; the de-skilling hypothesis corresponds to the "heroic" view of invention.

But far less evidence supports this aspect of the de-skilling hypothesis. At least since Adam Smith [1776], economists have recognized that factory workers develop skills on the job. Historical evidence suggests that economic actors appreciated this effect and David [1975] found strong evidence of learning-by-doing at early textile mills. ${ }^{1}$ If learning-by-doing involves a substantial human capital investment, then the technology of the Industrial Revolution might not be inherently de-skilling.

Moreover, as I elaborate below, the evidence that factory workers had low wages, little formal training, monotonous work, low status, etc. does not imply that employers made little human capital investment, especially in capital intensive, high-throughput industries. That is, depending on precisely which definition of skill one uses, de-skilling may describe aspects of the change in work conditions, yet fail as a complete description of technological change. Furthermore, as Crafts [1995] and Mitch [1999] suggest, the effect of factory skills on technology may also be important for understanding economic growth. Perhaps the slow development of these skills affected the slow growth of per capita output during the Industrial Revolution.

\footnotetext{
${ }^{1}$ For instance, see Ford [1923] and the textile mill agent quoted from 1859 by Shlakman [1935, p. 147] (see below). Late nineteenth century psychologists measured "learning curves" for individuals performing simple tasks [Bryan and Harter, 1897, 1899]. Twentieth century economists measured plant learning curves [Wright, 1936], formalized the notion of "learning-by-doing" [Arrow, 1962].
} 
This paper explores several aspects of the skills required of mule spinners and power loom tenders in ante-bellum Lowell, Massachusetts using micro-data. I make four principal empirical findings that support the idea that new skills developed by ordinary workers were critical to the adoption and efficient implementation of these technologies. First, employers made substantial human capital investments in these factory workers in the 1840's. Employers' investments supplemented employee investments and the total investments were comparable to those made by craft apprentices.

Second, most of the substantial growth in labor productivity over two decades can be attributed to growing skill levels of individual workers. Very little can be attributed to either exogenous technical change or generalized organizational learning. Greater investment in human capital permitted "stretching out"- deepening physical capital by increasing the number of looms per worker.

Third, the employer's investment in human capital was constrained by the nature of the labor supply and changed as the labor supply changed. In particular, high labor turnover implied high "depreciation" of human capital, limiting the profitable level of investment. When the labor supply gradually became more stable, human capital became more profitable and employers responded by deepening their investments.

Fourth, employers changed labor policy (thus changing social institutions) in a way that increased their return on this investment. The initial adoption of the power loom was accompanied by a new labor supply based on literate Yankee farm girls. I show evidence that literacy was critical to the profitable adoption of this new technology. Later, employers changed labor supply. In the 1840s more immigrant and illiterate workers were hired. This switch in policy encouraged the growth of a more experienced and stable workforce with higher returns on human capital. I show that these higher returns were profitable then, but not earlier.

These results suggest that the technology of the cotton industry cannot be adequately described as de-skilling. The new technology did not replace worker skills with machines, rather traditional craft skills were replaced by machines and new skills of a different sort. The new work force was, at times, illiterate, lacking formal training and poorly paid by comparison to skilled crafts. Yet at other times, literacy was important.

Furthermore, the historical process of technological change was more complex than suggested by the de-skilling hypothesis. Employers' concerns with the development of worker skills appear to have affected the pace and manner in which the new technology was implemented. The adoption and efficient implementation of the power loom were as much social innovations as technological innovations; firms experimented with different social arrangements for acquiring a 
skilled labor force. From this perspective, the innovation of the power loom was a broad social process, driven by more than an elite of inventors and entrepreneurs.

Previous researchers have explored human capital development in the factories. Boot [1995] obtains estimates of the human capital investments made by male workers in the Lancashire cotton industry. His estimates correspond quite closely with my estimates for male cotton mule spinners in Lowell in the 1840's. However, in addition to this investment made by employees, I find a much larger investment made by employers in the human capital of their employees.

Several researchers have studied the sustained rapid labor productivity growth at Lowell during the 1830s and 1840s [Davis and Stettler, 1966, McGouldrick, 1968, Zevin, 1975, David, 1975, Nickless, 1979, Williamson, 1972]. David and several others find strong growth in the multi-factor productivity residual, which David attributes to learning-by-doing. However, this learning effect could arise from worker skills or instead, as Zevin [1975, p. 5] suggests, from managerial or "organizational" learning. Using data on individual workers, I find that individual experience, and the associated human and physical capital investments, explain almost all of the growth in labor productivity. This implies that labor productivity grew over two decades as firms found ways to increase the skill level of the workforce.

Other researchers have also studied the link between the labor supply and the implementation of the technology. Ware [1931] and Josephson [1949] attributed these developments to changing employer motivation: philanthropy gave way to competition. Philanthropic motives may have played a role, but counterfactual calculations based on the human capital model provide a direct economic motivation.

Lazonick and Brush [1985] give another explanation that in many ways represents the worker's perspective on what I present from the employer's perspective. They argue that employers sought to intensify work, demanding greater effort, and that workers resisted this intensification by leaving (or in a few cases by striking). Irish and illiterate workers had fewer alternative opportunities, hence they were less willing to resist and so they experienced greater work intensification. From the employer's perspective, lower resistance meant lower turnover. And learning to operate three or four looms surely required greater effort than two. Thus this explanation is not at odds with the human capital model. However, the human capital model provides a more complete picture of the employer's interests. In particular, it explains why firms switched to three looms per worker before immigrants and illiterate workers entered the workforce in large numbers.

At a more general level, E. P. Thompson [1964] argues that a self-disciplined working class was critical for the adoption of this new technology. The argument here is similar, but more 
specific. Although such broad social changes also have a role in my model, I measure and explore the importance of specific skills learned on the job. This is significant because the Yankee farm girls arguably may have had greater self-discipline than the illiterate immigrants who replaced them.

The next section develops a simple model of on-the-job learning for many of the technologies of the Industrial Revolution. Section III estimates human capital investments. Section IV explores how firms decided to invest in human capital and V concludes.

\section{A Model of Factory Skills}

\section{Individual Learning Curves}

As Landes describes it, the technologies of the Industrial Revolution worked on a principle of replacing some skilled manual operations with power-assisted machinery. For example, the mule spinner, who spun cotton on a thousand spindles assisted by steam power, replaced the cottage spinster who spun on a single manually powered spindle. Yet although multiplying the number of spindles per worker increased throughput, it also increased defects, often by a more than proportional factor. ${ }^{2}$ Defects idled the expensive machinery, lowering the utilization rate. This, in turn, put a premium on worker's precision and reliability. Workers who allowed fewer defects and who fixed them faster would realize a higher utilization rate and higher productivity.

There is evidence that nineteenth century firms were quite concerned with issues of utilization and defects. Mule spinners were assisted by "piecers" to fix breaks ("piecing” together broken ends of yarn). In Stanway's survey of 151 Lancashire cotton mills in 1833, piecers comprised 59\% of the labor force in mule spinning and much of the spinners' labor was occupied with piecing as well [Parliamentary Papers, 1834, XIX, D.1, p. 125]. The piecers' wages figured prominently in contemporary evaluations of various spinning technologies, including mule carriages with a greater number of spindles [Parliamentary Papers, 1834, XIX, D.1, p. 119] and the "self-acting" (automatic) mules [Montgomery, 1840]. Indeed, von Tunzelman calculates that additional piecing costs made the self-acting mule uneconomical for fine yarns in 1835 [1978].

Similarly, estimates of idle time and effective throughput are found in calculations for power looms [Montgomery, 1840, p. 142, Ure, 1836, Vol. 2, p. 312]. Lyons [1987] cites data that well-operated power looms of the 1830's achieved utilization rates (actual production rate divided by machine rate) from $75 \%$ to $80 \%$.

\footnotetext{
2 In extreme cases, for instance, all the threads on a spinning mule could break at once, causing a "sawney" and a substantial loss in productivity [Catling, 1970].
} 
But it was also known that new hires would achieve a much lower rate of utilization and hence their production was far less. In 1859 the managing agent of a Chicopee mill wrote that it was desirable "to induce [new hires] to remain more than one year which is all that our contract requires of them. They will be worth more to us the last six months than they are the first twelve [Shlakman, 1935, p. 147].” That is, productivity and utilization doubled after a year. In other words, workers climbed individual learning curves.

The experience of cotton industry workers in ante-bellum Lowell, Massachusetts demonstrates the significance of learning curves. I obtained individual learning curves for mule spinners from the records of the Hamilton Manufacturing Company, which opened up a spinning room with mules in June of 1847 [Hamilton, v. 315, 514] $]^{3}$ and for power loom tenders ("weavers") for Lawrence Co. Mill No. 2 from 1833 to 1855.

Inexperienced workers at Lowell began work as "dayhands"—receiving a daily wage while they learned their skills on-the-job with assistance from more experienced workers. Once they achieved a base level of proficiency, they became "piecehands" or "job hands," paid by the piece. Sometimes new hires began piecework immediately; I assume these workers had previous experience.

At the Hamilton Co. Mill D spinning room, most of the spinners were not hired until the beginning of the July 1847 payroll period. They required six months to graduate to piece rate and their efficiency continued to improve after that. Figure 1 shows the average daily earnings for piecehands, which serves as a measure of productivity. ${ }^{4}$ This graph suggests that full proficiency required somewhat over a year to achieve.

Of course, contemporaries considered mule spinners to be more skilled than most other factory workers. More extensive data and a larger sample size are available for weavers in Lowell who tended power looms, a job considered less skilled and performed largely by young women (see Appendix for description of this data set). Lawrence Manufacturing Co. Mill No. 2 began operations in November of 1833. For workers who entered the Upper Weaving Room from 1833 to 1836 , the average "training period" — that is, the period spent on day wages—was 24.7 days. ${ }^{5}$

Figure 2 displays the mean yards of cloth per hour produced by weavers according to their months

\footnotetext{
${ }^{3}$ These were common hand mules (power-assisted, but not self-acting), judging by their valuation of $\$ 2$ per spindle in an 1852 inventory [Hamilton, v. 19].

${ }^{4}$ Hamilton Company produced yarns ranging from 14 count to 40 count and spinners were paid different piece rates depending on the count. For this reason, daily earnings provides a balanced measure of productivity as long as piece rates did not change during the period observed. It is also possible that some of the productivity improvement shown was the result of improvements other than increases in human capital.

5 This figure excludes workers who spent no time on day rate-these were presumed to have previous experience—and those workers who spent more than 72 days on day rate. The latter consisted primarily of "permanent" dayhands who taught new workers and served as utility workers.
} 
on the job. During this period workers tended two looms, implying a constant capital-labor ratio, so yards per hour provides a measure of multi-factor productivity. Workers achieved full proficiency after about six months.

During the 1840's, conditions in Mill No. 2 changed substantially-workers tended more looms and the workforce included fewer literate and more immigrant workers, but also more workers with prior experience. Starting in April of 1842, workers tended three and, later, four looms each. For the period from April 1842 to November 1855, new hires spent 32.6 days on day wages on average. And as shown in Figure 2, this group did not reach full proficiency until they had worked nearly a year. Thus by the 1840s the learning periods were substantially longer, but still much shorter than typical apprenticeships.

The learning curves in Figure 2 can be attributed almost entirely to changes in utilization as new workers acquired greater skill. ${ }^{6}$ All the looms in the Upper Weave Room were typically run at a fixed rate and departures from the maximum rate of output can be attributed to idle time. Assuming that fully trained workers operated at $80 \%$ utilization, then, during the first month on the job, the utilization rate was only about $21 \%$ for workers in 1833-36 tending two looms, and was about $17 \%$ for workers in 1842-55 tending three or four looms.

Skill was clearly important in achieving reasonable utilization of this relatively expensive equipment. This kind of learning process has been described as a process of trial-and-error search [Jovanovic and Nyarko, 1995, Muth, 1986, Auerswald et al, 2000]. In these models, productivity follows a "learning curve"-over time, through experience under different conditions and with repeated trials, a worker's productivity increases as knowledge of efficient techniques is acquired.

After a certain level of productivity is reached, the worker stops searching and uses the best technique found. ${ }^{7}$

\section{A Model of Utilization and Learning}

This general description of individual learning curves can be formalized in a simple model of an individual production function. Let $y$ be the output per worker-hour, let $n$ be the number of machines per worker (spindles or looms), let $q$ be the maximum output rate per machine, and let $u$ be the utilization rate. Generally then

\footnotetext{
${ }^{6}$ It is possible that the increases in productivity might arise from exogenous technical change or plant-level learning effects. This is, however, unlikely for two reasons. First, these charts display averages for different cohorts; any general productivity improvements that occur between cohorts would be averaged out (this is not the case with Figure 1, however). Second, the charts plateau rather rapidly, showing no significant productivity gain after the initial learning period. This visual observation is supported by a regression analysis below.

7 This property of "optimal stopping" is a general feature of search models where there is an opportunity cost or direct cost of search.
} 


$$
y=n \cdot q \cdot u \text {. }
$$

Now $u$ will be a function of both $n$ and of the worker's skill; specifically, $u$ will decrease with $n$ and will increase with skill. The discussion of Figures 1-2 above reveals further points about skill: 1) Skill increases with work experience, $x$; 2) But only up to a point, that is, only in the domain $x \leq \bar{x}$, and 3) The effective training period also varies (increases) with $n$, that is, $\bar{x}=\bar{x}(n)$. Using these insights, I define "effective experience" as

$$
z(x, n) \equiv \min (x, \bar{x}(n)) .
$$

Then the individual production function can be written

$$
y(z, n)=n \cdot q \cdot u(z, n) .
$$

Below I estimate individual production functions of this form.

Now low initial productivity for a new employee implies a learning cost. A standard measure of human capital investment is discounted foregone output [Becker, 1993, pp. 30-33]. This can be seen in a simple model in discrete time, $t=0,1, \ldots$, where all learning occurs during the first period ( $\bar{x}=1$ ), and employees never terminate employment (see Figure 3). Suppose that an employee at the firm earns $w_{0}$ during the training period and $w_{T}$ thereafter. In alternative employment this employee could earn $w$. This employee faces an opportunity cost (that is, a human capital investment) of $I_{w} \equiv w-w_{0}$ that earns a return of $w_{T}-w$ in each subsequent period. Now in a competitive labor market, the employee will be indifferent between working at the firm and taking alternative employment, that is, the present values of both income streams will be equal. When this is true, the return on investment, $w_{T}-w$, will equal $r \cdot I_{w}$, where $r$ is the discount rate. Then it is easy to show (see Figure 3) that the worker's investment is

$$
I_{w} \equiv w-w_{0}=\frac{w_{T}-w_{0}}{1+r}
$$

the discounted quantity of "foregone" wages.

Similarly, given product price $p$ and capital rental (per machine), $c$, the firm will earn profits per worker of $\pi_{0}=p \cdot y(0, n)-w_{0}-n \cdot c$ during the first period and $\pi_{T}=p \cdot y(\bar{x}, n)-w_{T}-n \cdot c$ thereafter. If the firm can achieve profits of $\pi$ in other activities, and if capital markets are in equilibrium, then the firm's human capital investment is

$$
I_{f} \equiv \pi-\pi_{0}=\frac{\pi_{T}-\pi_{0}}{1+r}
$$

and total human capital investment is 


$$
I \equiv I_{w}+I_{f}=p \cdot C, \quad C \equiv \frac{y(\bar{x}, n)-y(0, n)}{1+r}
$$

where $C$ is the discounted quantity of foregone output.

In the Appendix, I extend this analysis to multiple periods so that (4) and (6) become

$$
I_{w}=\sum_{x=0}^{\bar{x}} \frac{w(\bar{x})-w(x)}{(1+r)^{x+1}} \text { and } \quad C=\sum_{x=0}^{\bar{x}} \frac{y(\bar{x}, n)-y(x, n)}{(1+r)^{x+1}} .
$$

These equations hold also when employee separations are allowed after the training period. Wages and labor productivity can be observed for each period and for the plateau level. Thus the total human capital investment and also the worker's share can be calculated without explicitly assuming a value for the alternative wage (but assuming $r$ ). Below I check this calculation with one using an alternative wage. Also, these measures ignore separations occurring during the training period. In the Appendix, I also describe a procedure for calculating human capital investment allowing for separations during training. Both sets of measures are estimated below.

Note that the total human capital investment depends on the individual production function, (3), and thus on the firm's choice of machines per worker, $n$. That is, the firm jointly chooses the capital intensity and the level of human capital investment. This differs from other treatments where human capital is considered exogenous to the firm. Much of the analysis below concerns how firms make this decision to maximize profits. In the Appendix, I derive an expression for the steady state profits of the firm, assuming that the firm replaces workers who quit or are fired:

$$
\bar{\pi}=p \cdot y(\bar{x}, n)-w-n \cdot c-(d+r) \cdot I(n)
$$

where $d$ is the permanent employee separation rate. ${ }^{8}$ This equation has a simple interpretation. The last term represents the rent on human capital. The separation rate acts like "depreciation" of human capital: as workers leave and are replaced, the last term represents the cost of training replacement workers plus the return on investment. Note that (8) depends on total human capital investment independently of the firm's share. This means that firms can choose the most profitable level of investment without directly considering how the investment is shared.

This equation provides a useful framework for analyzing aspects of firm behavior below. Note that the last term could be substantial — separation rates in Lowell were sometimes 10\% per month or more — and separation rates are not entirely exogenous. For instance, firm hiring

\footnotetext{
8 As noted in the Appendix, in a model where the human capital investment is shared between workers and firms and where workers can leave one employer and use their skills at another, $d$ is the rate of permanent separations from the industry.
} 
practices could influence the rate of separations. Thus the choice of capital intensity also involved consideration of different labor policies.

\section{Measuring Learning and Human Capital for Factory Workers}

\section{Measuring human capital of the unskilled}

Using these definitions, I measure the human capital investment made in the Hamilton Company mule spinners and the Lawrence Company power loom weavers. I perform these calculations based on the mean labor productivity and mean wages by month of experience for balanced panels of workers using both estimation methods. (Separation rates during training are unavailable for the Hamilton sample and so only the first method is used.)

These estimates are shown in Table 1. During the 1830's loom tenders required an investment of $\$ 33$ by the first measure and $\$ 47$ by the second measure. By the 1840's this investment increased to $\$ 95$ by the first measure and $\$ 162$ by the second. The Hamilton Company mule spinners required an investment of \$314 using the first measure. Thus by the 1840's, male mule spinners required a human capital investment of over $\$ 300$ and female loom tenders required about half that amount.

The workers' share of this human capital investment was much smaller. Loom tenders invested only $\$ 6.42$ during the first period and \$23.31 during the second (using the second method, \$9.03 and \$32.39 respectively). Mule spinners invested \$109, closely matching Boot's [1995] estimate of $£ 22$ 10s (\$108) for the investment by Lancashire male cotton workers in 1833.

The methods used to calculate these investments do not explicitly assume a value for the alternative wage. To check these calculations, I compared the calculation for loom tenders during the 1830s (ignoring separations) to calculations made using two different alternative wages: the wages of Massachusetts female school teachers (\$11.28/month) and of New England females in cotton manufacturing from Goldin and Sokoloff's [1984] regression analysis for 1832 (\$11.98/month). These calculations generated estimates of $\$ 3.87$ and $\$ 5.04$, respectively. These figures are somewhat lower than my estimate of $\$ 6.42$, but the "true" alternative wage must take account of compensating differentials (for factory hours and discipline) and selectivity (loom tenders were among the higher "quality" cotton workers).

The estimates for total human capital investment compare favorably with estimates of the training costs of apprentices. Apprentices' human capital investments can be estimated several different ways. Using British data from 1906, Elbaum [1989] makes a "generous estimate" that annual training costs were about 30 to 40 percent of the apprentice wage. He estimates that 
apprentices in 1906 earned about 3s less per week than youths in other employment. More [1980] reports somewhat smaller differentials. Assuming a six year apprenticeship and a 5\% discount rate, Elbaum's generous figures imply that the present value of training costs was no more than $£ 40$ or about $\$ 190$ in 1906. This suggests that training costs in the 1840's were significantly less than $\$ 190$ - real training costs were unlikely to be greater in an age of simpler technology and nominal wages were about 50\% higher in 1906 than in the 1840's in Britain. Moreover, American skilled craftsmen earned roughly the same pay as their British counterparts in the early nineteenth century [Brito and Williamson, 1973, Rosenberg, 1967].

Internal rates of return provide another way to estimate the training costs of apprentices. Elbaum and Singh [1995] also estimate the internal rate of return on apprentice training in Britain in 1906. Using a skill premium of just under $40 \%$ (relative to semi-skilled occupations), they find an internal rate of return of $24 \%$. In the antebellum United States, Margo finds skill premia of $32 \%$ for carpenters and $43 \%$ for masons relative to teamsters, a semi-skilled occupation [Margo, 2000]. Using an internal rate of return of $24 \%$ and wages of $\$ 1.25$ for carpenters and $\$ 1.50$ for masons, training costs were, respectively, $\$ 165$ and $\$ 253 .{ }^{9}$

Taking both of these estimates into account, male craftsmen in the 1840s probably required an investment of from $\$ 150$ to $\$ 250$. Thus the human capital investment in "unskilled" factory jobs was as large as, if not larger than, the investment made in traditional craft apprenticeships. Moreover, this investment was made in workers who had rather brief careers in the mills. Among weavers, turnover was very high, many workers did not complete even these brief training periods, and those who did only worked for several years in the mills [Dublin, 1979]. Nevertheless, after 1842 the weavers, who were largely women, received human capital investments that were nearly as large as those made in male skilled craftsmen (and much larger relative to their respective annual wages).

And contemporaries were aware of the significance of this investment:

"Operatives entering the mill at once receive pay. In other arts they are obliged to go through some expensive process of learning. The young woman from the country, employed at first as a spare hand, and a pupil to the business, receives fifty-five cents per week (sic) besides her board. Thus the companies educate nearly all their hands, and as these hands are entirely changed every few years, they have at all times thousands in their pay as mere learners." [Miles, 1846, p. 112]

For the firms, these investments were not particularly large compared to the investment in physical capital per worker (see Table 1). But for the workers, these investments were quite

\footnotetext{
${ }^{9}$ This calculation assumes that the apprentice earned a constant differential less than alternative employment for six years, the same for one year, and then earned a premium for 30 years. The discount rate was $5 \%$. A lower premium or higher internal rates of return reduce estimated investment. I also assume year-round work which may mean that investments are overstated for masons.
} 
substantial, especially given the uncertainty of the job match. Thomas Dublin estimates the property assets of the fathers of the Yankee mill girls as \$338 in 1830 and \$960 in 1850 [p. 35]. The human capital investments thus represented a significant portion of family wealth, especially for an uncertain and short-term investment. And after 1845 many of the weavers were Irish immigrants who had no such wealth. As shown in Table 1, the investments were also large relative to a trained worker's annual pay. It is not surprising then, that in contrast to apprenticeshipwhere workers effectively bore the full cost of human capital investment [Elbaum and Singh, 1995] — factory workers contributed only a fraction of the total investment as seen in Table 1.

These calculations imply that the mills paid workers less than their marginal product - the mills earned rents that permitted an adequate return on their human capital investment. ${ }^{10}$ In classic human capital theory, this occurs when the human capital is firm-specific [Becker 1993, Hashimoto, 1981]. Although loom tenders had skills that were industry-specific, by 1855 over $70 \%$ of the new hires at Lawrence Mill No. 2 had previous experience (see below). Many must have gained this experience at other firms, so the skills could not have been very firm-specific.

Recent theoretical and empirical work finds other instances where firms earn rents and pay for general training. ${ }^{11}$ Following the analysis of Acemoglu and Pischke [1999], if the mills could earn rents (for any reason), then, given piece rate wages, they would have had an incentive to pay for general skills-more productive workers were more profitable. At Lowell, the mills had a degree of monopsony power. The mills, in fact, set wages jointly and in numerous cases they changed wages in unison [Dublin, 1993, pp. 10, 21, McGouldrick, 1968, p. 37]. Moreover, the mills shared a common supply of waterpower, they shared patents and they had interlocking directorates. This gave them the ability to sanction potential defectors. Of course, mills in other towns could attempt to hire away experienced workers, however, relocation costs were significant and temporary workers were usually hired under one-year contracts. The associated costs provided the Lowell mills room to earn limited rents.

Thus the workers at Lowell appear to have been paid less than their marginal product. For this reason, low wages, relative to artisans or clerks, cannot be taken as evidence in support of the de-skilling hypothesis - the firms, not the workers, earned most of the returns to human capital.

Nor do the brief formal training periods or lack of educational requirements support the de-skilling hypothesis. For example, Marglin [1974] argues that significant learning may apply to the work of "musicians or dancers or surgeons," but not to the "run-of-the-mill work that

\footnotetext{
${ }^{10}$ For example in 1834 (Table 3) the rents (“depreciation”) were $1.3 \notin$ per hour over wages of $4.3 \notin$ per hour.

11 See Acemoglu and Pischke [1999] for a literature review.
} 
characterizes most production." Indeed, the power loom tenders only had training periods (as day hands) lasting about a month.

But the length of formal training does not accurately measure human capital investment for two reasons. First, the duration of training does not capture the intensity of resources expended during training. The clothier's apprentice did not typically sit at a loom from his first day, but spent many months performing ancillary tasks to assist his master. The factory loom tender did work on a loom from her first day and looked after a substantial capital investment. The rapid throughput of the factory technology entailed a large opportunity cost for this equipment.

Second, there is an important difference between the formal training period and the time over which a human capital investment is made. When learning occurs through trial-and-error adaptation on-the-job, the entire duration of learning extends well beyond the formal training period as above. On the other hand, the length of an apprenticeship may exceed the duration of actual learning - the later years of an apprenticeship permit the master to recoup his investment and little or no learning may take place [Elbaum, 1989, Elbaum and Singh, 1995].

Factory workers have also been described as "de-skilled" for lacking job control [Braverman, 1974] and as unskilled by social construction [Valverde, 1988]. Nevertheless, these workers did have important skills that were developed only with substantial investments.

Finally, these results suggest a re-interpretation of Sokoloff's finding [1984] that antebellum manufactories, prior to substantial mechanization, experienced productivity growth associated with a division of labor and a labor force employing women and children. Clearly, this transition was not necessarily de-skilling, but rather suggests a switch to a different type of skill with, perhaps, significant human capital investment. The division of labor would have simplified tasks, facilitating learning-by-doing. This interpretation suggests that the development of these new skills preceded the widespread implementation of new mechanized technologies that required such skills.

\section{Accounting for Productivity Growth}

Productivity studies have long recognized impressive growth in labor productivity throughout Lowell in the 1830s and 1840s [Davis and Stettler, 1966, McGouldrick, 1968, Zevin, 1975, David, 1975, Nickless, 1979, Williamson, 1972]. Several of these studies find substantial growth in multi-factor productivity, which David attributes to learning-by-doing. But David's analysis does not distinguish the source of this learning effect, only that the effect appears to be related to experience. Several explanations are possible. Inventors could make minor experience- 
based improvements in the technology; managers could learn to streamline operations; workers could learn new skills.

Using the micro-data for Lawrence Mill No. 2, a regression analysis shows that worker skills account for almost all of the growth in labor productivity. The individual production function represented by equation (3) can be estimated. To do this, I need to specify a functional form. Following the learning-by-doing literature (and by inspection of Figure 2), I represent $y$ as a power function of $z, y \propto z^{\gamma}$. A power function is also a flexible functional form for estimating the experience necessary to complete learning, $\bar{x}(n)=b_{k} \cdot n^{\alpha}$. Assuming a normal error, $\varepsilon$, and initially assuming a constant time trend, then a basic log labor productivity function for the $i$ th individual at time $t$ is

$$
\begin{aligned}
& \ln y_{i t}=b_{0}+b_{n} \cdot \ln n_{t}+b_{z} \cdot \ln z_{i t}+b_{t} \cdot t+\varepsilon_{i t} \\
& z_{i t} \equiv \min \left[x_{i t}, b_{k} \cdot n_{t}^{\alpha}\right]
\end{aligned}
$$

where the $b_{j}$ and $\alpha$ are to be estimated. The coefficient $b_{t}$ captures Hicks-neutral productivity change. Any productivity growth arising from exogenous technical change or managerial learning will be captured by this coefficient as a growth rate.

This specification allows the learning period to be estimated jointly with the learning slope coefficient. This form is highly non-linear, so I estimate it using maximum likelihood. The first column of Table 2 shows an estimate without individual characteristics. All of the experiencerelated coefficients are highly significant. The estimates of $b_{k}$ and $\alpha$ generate learning periods of 6 months for two looms per worker and 12 months for three looms per worker, corresponding well with Figure 2. Note that the time coefficient, significant only at the 5\% level, implies a small residual rate of productivity growth. Note also that machinery has a negative effect on productivity without an accompanying increase in skill. ${ }^{12}$

The remaining columns explore year dummies, individual characteristics and individual fixed effects. The basic coefficients seem robust to these changes as well as to alternative measures of effective experience (not shown here). The coefficients on the characteristics of individual workers (columns 3, 4 and 5) are discussed below.

These results indicate that the growth in labor productivity—which averaged $3.4 \%$ annually from 1834 to 1855 - arose largely from the deepening of human and physical capital. The time trend is at best $0.5 \%$ and at worst, it is negative. In other words, at most only about $15 \%$ of

\footnotetext{
12 The number of looms per worker is correlated with the time variable, raising the possibility of multi-collinearity. To test for this, I calculated the Belsey, Kuh, Welsch [1980] condition number for the linear regressions. These suggest there is sufficient independent variation in $n$ to produce reliable estimates.
} 
the growth in average labor productivity can be attributed to technical change or managerial learning. Although there were some minor technical improvements to the looms, these appear to have had little effect on productivity, a result also found by Lazonick and Brush [1984]. ${ }^{13}$ Managerial learning also appears to have played little role. On the other hand, the mean effective experience, $z$, increased from 96 days in 1834 to 353 days in 1855, an annual rate of $6.1 \%$ and the looms per worker increased at a $2.7 \%$ annual rate. Applying the coefficients from the regressions, this means that deepening human and physical capital accounts for productivity growth of about $3.1 \%$ per year. Thus the productivity growth was achieved mainly by workers learning new skills (and tending more looms), supported by human capital investment.

\section{Human Capital Investment and the Labor Supply}

\section{The Stretch-Out of 1842}

But why did firms take so long to deepen this investment?

To answer this question, I use equation (8) to analyze the profitability of different human capital investments at different times. The profitability of an investment depends on price, $p$, the wage, $w$, and the separation rate, $d$. The first two are market variables, but the separation rate may depend on more complex social conditions. The early textile industry did not have an established industrial labor force, a ready pool of trained workers to hire, or institutions to select, train and maintain a stable skilled workforce. Because skill was important for factory work, the most profitable use of new technology depended on a skilled labor supply with relatively low turnover. And this developed only slowly and with some substantial social innovation. This section explores the relationship between the technical growth of the cotton industry and changes in labor supply.

First, I explore the effect of the separation rate on capital deepening as illustrated by the "stretch out" of 1842. In April of 1842, Mill No. 2 of the Lawrence Company switched permanently from two looms per worker to three looms per worker (four looms after 1851). Prior to then, each worker tended two looms except during occasional periods when waterpower was rationed or when labor supply was insufficient. Beginning in early 1842, the mills in Lowell began experimenting with different numbers of looms per worker and different loom speeds [Dublin,

\footnotetext{
13 Lazonick and Brush performed similar regressions including dummy variables for a let off motion on the looms that was installed in 1835 and a new cotton picker in 1844. Neither had a statistically significant effect on productivity. Lazonick and Brush also found that overall or managerial effects did not have a significant positive effect on productivity. They did not, however, calculate the overall contribution of learning and effort to the long run growth in labor productivity.
} 
1993, p. 109]. In April 1842, all weavers in the Upper Weave Room of Mill No. 2 appear to have been assigned three looms. ${ }^{14}$

The initial impetus for this transition appears to have been depressed demand, not technological change. James Montgomery was in Lowell at the time he was revising Cotton Manufacture. A thorough observer of all things technical, he attributed the change to poor demand, not anything technical [1840, p. 132]. He opined that the mills would revert to two looms per worker once business revived, but this did not happen.

Some thumbnail calculations demonstrate why this change was permanently beneficial and also why it might not have worked in 1834. Table 3 illustrates some simple calculations based on Equation (8) for two and three looms in 1834 and 1842.

This equation uses the rate of permanent separations from the industry, $d$, however, the data only reveal separations from the Upper Weaving Room-workers leaving this room could go to other weaving rooms in this or other mills. On the other hand, this room hired experienced workers from other mills. A certain percent of the workers leaving any particular mill were retained in the Lowell labor force and could be hired by other mills, perhaps after a stint of unemployment. To estimate this retention rate, I assume that these flows in and out of the Upper Weaving Room were in equilibrium. That is, for any period, the number of workers who left the Upper Weaving Room and found work in another weaving room equals the number of experienced workers hired into the Upper Weaving Room. The retention rate is then the number of experienced workers hired divided by the total number of separations. The rate of permanent separations is the gross rate of separations times one minus the retention rate. I estimate the number of experienced hires as the number of hires who spent no time on day wages during their first month.

The resulting values of net profit per worker-hour show a sharp difference: two looms were preferable in 1834, but three were preferable in 1842 . Two sorts of changes contribute to this difference: first, product price decreased relative to wages from 1834 to 1842 . Second, labor supply conditions improved by 1842 indicated by a lower separation rate and a higher retention rate. Each of these sources of change deserves further examination.

First, consider the role of wages relative to price. Equation (8) implies that higher relative wages may induce firms to invest more in human capital and employ fewer, but more skilled, workers per machine. That is, the cost of human capital investment is foregone output, $C$, and this is valued at the product price. But the resulting labor saving is valued at the market wage. When the wage is relatively high, the benefits are large and firms invest more. When the wage is low, the

\footnotetext{
14 Judging from changes in capital productivity, the speed of the looms was reduced and gradually restored to its original level over the next two years. Montgomery states that speeds were reduced by about 15\% [1840, p. 132 (notes added later)].
} 
benefit is not worth the cost and so human capital investment is low. In short, skill substitutes for labor when wages are high relative to prices. ${ }^{15}$

But the rise in the relative wage does not, by itself, explain the transition to three looms in Lowell. If the calculations for 1842 are repeated, but only price and wage level are allowed to change from 1834, two looms are still much more advantageous. The higher retention rate and the lower separation rate of the labor supply exerted a larger influence.

This suggests that human capital was decisive in the switch to three looms per worker. Firms could not have profitably used three looms in 1834 because high labor turnover inhibited the needed human capital investment. They had to wait for the maturation of the labor force. This appears to have occurred through the selection of a more stable employed workforce and also with the growth of a pool of experienced workers available for rehire. But this was a slow process that delayed the more efficient implementation of power loom technology. Because skills were important, technical change had to wait for maturation of the labor supply.

\section{Human Capital and Labor Policy}

Thus the mills responded to a more stable labor supply by deepening their investments in human and physical capital. Given that the mills improved their profits with a more stable labor supply, one wonders whether they pursued labor policies to actually foster labor stability. I argue that major changes in labor policy served, in fact, to maximize the returns on human capital of factory workers.

Historical accounts of the cotton industry have emphasized the close link between technical changes and changes in the labor supply. Prior to 1816, most cotton manufacturing took place under the so-called "Rhode Island" system first used by Slater [see Ware, 1931, Kulik et al, 1982, Tucker, 1984]. Whole families were recruited to live and work in mill villages often with company housing and a company store. An advantage of this system was that it provided a supply of child labor often with parental supervision.

A switch to the "Waltham system" accompanied the introduction of the power loom in 1816. At Waltham and Lowell, the mills predominately hired young, literate Yankee farm women for weaving positions. These women were largely hired at an age before they would customarily marry with the expectation that they would work only a few years at most. They came to Lowell

\footnotetext{
15 Note that this is definitely not a simple case of capital substituting for labor. In a standard two-factor model, capital productivity should drop substantially with a 33\% drop in labor per capital. But capital productivity remained nearly unchanged (Table 3 ) This result appears to be more general. In a cross-country comparison of cotton mills circa 1910, Clark [1987] finds that those countries with high relative wages employed more capital per worker, but they did not have lower output per machine. Clark discounts an interpretation involving experience, however, Clark's measure of experience is quite rough and unlikely to capture the effects measured here with richer data.
} 
from all over northern New England. Their time in Lowell was structured to be a rewarding cultural and intellectual experience; they lived in morally supervised boardinghouses, they were expected to attend church, they could attend cultural events and lectures and participate in producing a newspaper and other activities [see Dublin, 1993, for a more complete picture]. As seen in Figure 4, about 95\% of new hires were literate, above the average level of literacy for women at that time [Perlman and Shirley, 1991] and few women with Irish surnames were hired.

And another switch followed the transition to three looms per worker in the 1840s: the new labor force included growing numbers of immigrants and illiterate workers. The Lawrence Company began hiring more illiterate workers (see Figure 4) and, after 1845, more Irish workers. This change was gradual, however, and the majority of new hires were literate until 1855 and nonIrish until 1854. The boardinghouses and cultural institutions gradually lost support, and the labor force increasingly lived in local private housing.

Traditional historical accounts have identified changing motivation of employers as the cause of the simultaneous changes in technique and labor supply. Initially, the employers acted partly on philanthropic motives [Ware, 1931, p. 64]. Here the historians have followed the early hagiography of Francis Cabot Lowell who, after visiting Lancashire, established the Waltham system of manufactures to avoid the "corrupting and debasing influences which have almost universally marked manufacturing cities abroad" [Miles, 1846, p. 215, see also Appleton, 1858].

But according to this view, by the 1840s, more intense competition drove manufacturers to reduce wages, speed up (run the machinery faster) and stretch out (more machines per worker) [Ware, 1931, p. 113, 230, Josephson, 1949]. Manufacturers could get away with this greater "exploitation" because the mills began hiring Irish and "low class" New Englanders who were more submissive.

Yet explanations dependent on early employer paternalism are not entirely convincing. The Lowell employers did lower piece rates during the early decades (e.g., a large reduction in 1834). Moreover, employers could have hired allegedly docile Irish and "low class" girls during the early decades, but did not. ${ }^{16}$ It is hard to see why philanthropists would have spurned these needier classes, especially when they might have improved profits. More significant, the timing of this story is off. The stretch-out to three looms per worker occurred in 1842 before many immigrant or illiterate workers were hired and while the workforce was supposedly more resistant.

\footnotetext{
16 Of about 600 adult Irish in Lowell in 1835, only 50 were employed as factory workers; most Irish women went into domestic service, instead [Ware, 1931, p. 229]. Also, when Irish did enter the factories, they were assigned to low-paying departments [Dublin, 1993, p. 148], not weaving.
} 
18 - Skills of the Unskilled - February, 2002

Worker skills provide another explanation for the changes in labor policy. Whatever their philanthropic motives were, the employers may have also had solid economic motives based on maximizing the returns to human capital investments. From the perspective of worker skills, the main advantage of the Waltham system was its selectivity. In the early years, this allowed the mills to hire a select group of workers who could learn new skills quickly and reliably. Later, however, the Waltham system, based on a transient workforce of young women, proved a poor vehicle for building long term employment relationships. A workforce based on local labor, including immigrants and illiterates, was more suitable for the greater human capital investments after 1842.

The type of workers in the Waltham system demonstrates this selectivity. As noted, few immigrant or illiterate workers were hired and, unlike the Rhode Island system, the workers were young adults. Below I demonstrate that literate adults had a critical productivity advantage.

Also, this system had a strong job matching mechanism to select those individuals who were most productive. About one third of new hires (half of illiterate hires) would leave during the first three months on the job at the Lawrence Co., either because they found the work distasteful or their performance was unsuitable. In addition, discipline in the factory and in the boardinghouses served to select out those of immoral or insufficiently serious character [Gersuny, 1976]. Indeed, in the early days, the transient nature of the Lowell workforce was seen as an advantage because it avoided a permanent caste of "degraded" workers [Ware, 1931, p. 200].

In contrast, under the Rhode Island system, mills had only limited selectivity. Families were recruited as a unit [see Ware, 1931, p. 199-200]. This meant that the recruited families were likely to be poor and perhaps more often illiterate [Tucker, 1984, p. 79-80]. One mill owner described mill families as "often very ignorant, and too often vicious" [Smith Wilkinson cited in Ware, 1931, p. 200]. Although this remark may not be representative, the mills had limited choice of the families they could recruit. They also had limited choice over individual hires. Householders determined which family members would work, sometimes recruiting distant kin or outsiders to fill factory positions, and the householders controlled job assignments and supervised the work [Tucker, 1984, p. 148, 217].

But although the Waltham system had advantages for quickly developing skilled workers for a new technology, it failed to foster a stable workforce. First, literate workers were more likely to leave- they had better opportunities in the labor market (e.g., as schoolteachers) and perhaps also in the "marriage market." In a probit analysis of separation probabilities (not shown), after controlling for ethnicity, real earnings and experience, I found that literate workers' monthly separation rate was $4 \%$ higher than for illiterate workers after the initial three months. 
Second, once workers left a Waltham-style mill, they were less likely to be available for rehire. Only 9\% of the young women employed at Boott mills in 1841 came from Lowell [Ware, 1931, p. 219]. These workers tended to leave Lowell once they got married [Dublin, 1993, p. 264] and they very likely also left Lowell when they left the mill for other reasons. As a result, literate workers had a lower retention rate. From 1842 to 1855 I found the mean retention rate for literate workers was $51 \%$; for illiterate workers it was $70 \% .{ }^{17}$ Thus the transition that took place after 1842 was also a transition to a local labor force where many experienced workers, having left the mills, were available for rehire. But this pool of local labor included many immigrants and illiterates; of the workers residing in local private housing, only $45 \%$ were native born. ${ }^{18}$

Thus I argue that the shifts in labor policy reflected a changing tradeoff between selectivity and stability in the development of worker skills. The advantage of selectivity in the early years and the shift to stability in the 1840 's is illustrated by counterfactual calculations concerning literacy using the human capital model. I find that literacy was critical for profits in the early years, including the initial adoption of the power loom before 1820. Literate workers were crucially more productive. During the 1840's, however, literacy progressively lost this advantage because illiterate workers were more conducive to a stable workforce.

\section{Literacy and Factory Skills}

Consider first the shift to a more stable workforce after 1842. I argue that once employers achieved the gains of a stable workforce in 1842, they then pursued a labor policy to foster an even more stable workforce allowing even greater skill investment.

Ironically, although literacy was critical to skill development in the early years (see below), in the 1850's greater human capital investment was achieved by hiring fewer literate workers. This paradox arises from the double-edged effect of literacy. Literacy increased worker productivity, but a literate workforce was less stable.

Consider first the positive effect of literacy. The job of tending a power loom did not involve reading or writing. One might assume, therefore, that literacy was of no significance to this job. Certainly many illiterate workers held factory jobs. Indeed, Mitch [1992] has documented the low level of literacy among English factory workers.

\footnotetext{
${ }^{17}$ Calculated as the number of experienced workers of the given type hired over the number of workers of that type who separated during the period as discussed in the text. This method very likely understates the retention rate for illiterate workers because very few were in the workforce at the beginning of this period.

18 Dublin [p. 143] finds that in 1850 that $55 \%$ of the native born lived in company housing while $39 \%$ of the total workforce did. Yankees comprised $61.4 \%$ of the workforce. Therefore $61.4 \%$ x $(100 \%-55 \%) /(100 \%-39 \%)=45 \%$ of the workers living in private housing were native born.
} 
But contemporaries in Lowell felt education was important for weavers. Miles argued that Lowell operatives were superior to their English counterparts because of their education [1846, p. 130]. In 1841, Horace Mann, the Secretary of the Massachusetts State Board of Education, obtained evidence from Lowell employers suggesting that literate operatives earned $18 \%$ to $27 \%$ more than illiterate operatives [Dublin, 1993, p. 150]. Dublin disputes this evidence, arguing that mill agents assigned educated Yankee workers to better jobs and these statistics did not adequately control for job placement.

But evidence from the Lawrence Company reveals that literate workers were about $12 \%$ more productive, all else equal. Columns 3 and 4 of Table 2 show regressions on worker monthly productivity that show literate workers were $17-18 \%$ more productive. However, this estimate may be biased upwards because illiterate workers were more likely to quit during the first few months. To correct for this, in column 5 I regress the fixed effects from column 2 on individual characteristics (one observation per individual). Here literate workers are just over $12 \%$ more productive at a high level of significance (other characteristics were at best marginally significant). ${ }^{19}$

Although weaving did not involve reading and writing, literacy signaled higher productivity, apparently either because literate workers could learn better or were more used to performing patient detail work. But, as noted above, literate workers had a higher separation rate and a lower retention rate.

The combined effect of the greater productivity and higher separation rate is illustrated in Table 4. This repeats the simplified pro-forma calculations in Table 3 for the preferred number of looms in 1834, 1842 and 1854. But the calculation is performed separately for literate and illiterate workers in each year. In the columns for literate workers, both productivity and piece rate wages are $12 \%$ higher. Actual separation rates are included. ${ }^{20}$

These estimates understate the advantage of illiterate workers for two reasons. First, although mainly literate workers resided in subsidized boardinghouses [Dublin, 1993, p. 155], Table 4 ignores the cost of this subsidy. Second, Table 4 uses the same retention rate for both literate and illiterate workers, despite higher retention of illiterate workers (above). To the extent

\footnotetext{
19 As an unweighted OLS regression, this is consistent but not efficient, since the fixed effects will have lower variance for individuals with more monthly observations. I use standard errors that are robust to heteroscedasticity.

20 The separation rates are the averages for $1833-36$ for the 1834 columns, averages for $1842-50$ for the 1842 columns, and 1852-5 for the 1854 columns. The retention rates are for 1833-36, 1842, and 1852-55 for the three sets of columns. For simplicity, no adjustment was made for different quit rates during training.
} 
that each firm considered the benefit of the pool of experienced labor in its hiring decisions, illiterate workers would have a greater advantage. ${ }^{21}$

Despite this bias, Table 4 shows a slow, distinct shift of advantage in favor of illiterate workers. In 1834 literate workers were quite profitable, but the Lawrence Company would lose money hiring illiterate workers. By 1842, however, illiterate workers were profitable, though less profitable than literate workers-mills might reasonably hire a few illiterate workers with strong positive unobserved characteristics. By 1854 illiterate workers were significantly more profitable for four looms per worker.

As the economic advantage shifted toward illiterate workers, the mill began hiring a larger share of these workers. This occurred slowly at first after 1842 when still only a small percentage of hires were illiterate. As the mills began hiring more local workers, including immigrants and illiterates, the pool of these workers available for rehire grew. As can be seen in Figure 4, the percentage of new hires with experience grew and after 1845 this growth consisted largely of experienced workers who were Irish and/or illiterate. This, in turn, made illiterate workers more advantageous. Also, their separation rate declined as, perhaps, they found less discrimination. Most significant, the greater human capital investment with four looms per worker shifted the advantage further toward a stable workforce.

Thus employers appear to have changed hiring policy in the 1840 's not simply because their philanthropic instinct abated, but because it was profitable to do so. And it was profitable because worker skills mattered. Although this transition was de-skilling in the sense that more illiterate workers were hired, the actual human capital investments increased.

But if literacy was necessary for profits in 1834 , then it may also have been critical to the initial adoption of the power loom. To explore this possibility, I make calculations for a hypothetical manufacturer of coarse cloth in 1818. The first power loom weavers produced a coarse shirting similar to the cloth woven in Lawrence Company Mill No. 2. Production costs, and the benefits of literate workers, can be estimated by extrapolating backwards to 1818 from the figures for the Lawrence Company in 1834.

In Table 5, I calculate the cost per yard of the entire weaving process (spooling, warping, dressing and weaving) extrapolating figures for 1834 from Table 4 back to 1818. This backward extrapolation involves an adjustment for machine speed, capital costs and wages (see notes to Table 5). I assume the same separation rates, but allow no previously trained hires. I also make the same assumptions about the relative productivity and wages of literate and illiterate workers as in

\footnotetext{
21 Firms would realize a private benefit when workers it had previously trained were rehired at another weaving room in the same firm. Also, firms, given their close cooperation on other issues, may have partially internalized the externality of the pool.
} 
Table 4. Results for literate and illiterate workers under a Waltham system of employment are shown in the first two columns.

Under these assumptions, coarse shirting produced with literate workers in the Waltham system would have cost $2.9 \notin$ per yard to weave in 1818 ; with illiterate workers in the Waltham system it would have cost $3.8 \notin$ per yard.

The Rhode Island system differed in that it had lower selectivity (as above) and it also employed children. Although child wages were low, so was child productivity. Batchelder [1863, p. 75] argued that children would not earn enough on the power loom to cover their board. In any case, even mills outside the Waltham system typically hired young women to operate their power looms [Ware, 1931, p. 77]. Given these difficulties, children in the Rhode Island system would have produced less than the illiterate workers in Column 2. In Column 3 I make the (heroic) assumption that children in a mill family would produce at half the average rate of individually hired literate adults. This generates a cost for weaving of 5.1ф per yard, despite the lower wage.

These costs can be compared to the rates charged by the independent handloom weavers who contracted out weaving. Manufacturers had to realize significantly lower costs in order to invest in the new technology. ${ }^{22}$ Weaving rates were uncertain and fell after the War of 1812. The Troy Company paid handloom weavers $4 \frac{1}{3} \notin$ per yard for coarse shirting in 1818 and $3 \frac{1}{2} \phi$ in 1820; the Slater Company paid $5 \varnothing$ per yard in 1820 [Ware, 1931, Appendix D]. ${ }^{23}$ Thus the power loom was comfortably profitable when operated by high quality literate adults as in the Waltham system. But power looms were at best marginal and at worst plainly unprofitable when operated by illiterate adults or children, especially when these employees were not in jobs that matched their skills or temperaments. Thus in 1818 the power loom was only a sound investment when it was accompanied by a quality labor supply.

This result squares generally with the actual pattern of adoption. The manufacturers of southern New England, tied to a labor supply in mill villages, were slow to adopt the power loom. ${ }^{24}$ Slater did no power weaving until 1823 and continued to contract handloom weavers until 1827 [Ware, 1931, p. 74]. And to perform this weaving, he hired young women, many from outside the family system. Some attempts to adopt power weaving with the old style labor supply were unsuccessful. In Fall River, weavers were unable to produce enough to make adequate wages on piece work, and so they were paid by the day instead [Ware, 1931, 72-3]. Many small mills

\footnotetext{
22 For comparison see von Tunzelman [1978] and Lyons [1987] on the British adoption of the power loom

23 Slater appears to have paid above current rates for his weaving [Ware, 1931, p. 74-5], perhaps as a quality premium.

24 These mills often used a slightly different power loom, the so-called Scotch loom.
} 
survived as niche producers of fancier goods as opposed to the coarse goods that were produced in Waltham-style mills. But the large Waltham-style mills quickly came to dominate the industry [Ware, 1931, 85].

Thus Lowell was driven by more than philanthropy when he chose to recruit literate farm girls, to house them and provide them a desirable moral and cultural environment. The success of his business gamble depended very much on the ability of these weavers to learn new skills and to become highly productive. Thirty years later, however, the mills had a more stable workforce and a local pool of experienced workers available for rehire. Then the mill owners changed hiring policy in favor of longer employment relationships with greater investment in worker skill.

\section{Conclusion}

I have argued that the textile technology of the Industrial Revolution did not eliminate the skills of ordinary factory workers, rather it required the development of new skills. The textile firms financed the acquisition of these new skills primarily themselves. In order for this human capital investment to be profitable, however, the firms needed to find the right match of labor policies and social conditions. Regardless whether factory workers are classified as skilled or unskilled, the development of their skills posed a problem for employers and affected the pace and nature of technology implementation.

Consider for example, Habakkuk's argument [1962] that higher American wages were responsible for American firms choosing more capital intensive techniques than in Britain. In fact, the stretch-out of 1842 marked the major point of divergence between British and American power weaving techniques. Britain continued to assign two power looms per worker in the 1840s and British power weavers tended fewer looms than their American counterparts for the remainder of the century [Copeland, 1912, p. 90]. The analysis above suggests that wages may have exerted some influence, but that wages and prices were not decisive in inducing this change. Differences in labor skills and in product markets (e.g., greater standardization in America may have reduced the required human capital investment) may prove more significant. ${ }^{25}$

These skills also alter the picture of technological change. The reason firms took decades to invest in worker skills to the level of the 1850 s was that the profitability of this investment depended on a slowly changing labor supply and supporting institutions. The profitability of human capital investment improved as the workforce matured and as a pool of trained workers emerged in Lowell, encouraged by new labor policies.

\footnotetext{
25 Brito and Williamson [1973] argue that a lower skill premium in America permitted higher capital utilization. Harley [1974], on the other hand, argues that a greater supply of skilled labor in Britain allowed firms to substitute skill for capital. In these models, however, the skill premium is exogenous and is measured by occupational differences.
} 
In other words, the effective implementation of the power loom was a broad social process. In contrast, the hypothesis of skill-replacing technology implies that innovation occurred as an elite process driven by a few inventors, mechanics and entrepreneurs (in this case, Lowell and Moody). But the picture of power weaving in ante-bellum New England suggests that this innovation was as much a process of social innovation as of technological innovation. More generally, weaving in the nineteenth century appears as a series of social experiments designed to facilitate the acquisition of worker skills: first, the Waltham system where literate farm girls housed in company boardinghouses tended the first power looms (replacing the earlier model of mill villages, itself a social innovation). Then in the 1840 s, this gave way to a labor supply that also included immigrant and illiterate labor, now residing permanently in the factory town. This change permitted greater human capital investment and more productive implementation of the power loom. The end of the nineteenth century saw the adoption of the automatic loom and many more looms per worker. Saxonhouse and Wright argue [1984, Wright, 1986] that this technological innovation, too, was intimately connected to social innovations, particularly in the development of an adult male labor supply in the South.

From this perspective, social flexibility seems to have been an important element in the sustained innovation and productivity growth of the American cotton textile industry. American society was willing to permit a series of experiments that changed the social roles of women and immigrants, and that changed work and residence relationships. The British cotton industry appears to have had a similar flexibility with a different series of social experiments related to worker skill: parish apprentices, employment of women and children, "following up" as a method of training, and the emergence of mule spinning as a semi-craft occupation. This social experimentation contrasts with the situation in China where women were not permitted to work outside the home, ordinary cotton goods were produced almost exclusively within the household and this limited the adoption of new technology [Chao, 1977, Chapter 3, Goldstone, 1996]. Perhaps social flexibility was an important element promoting the sustained technological innovation seen in Britain and America during the Industrial Revolution.

\section{Appendix}

\section{Description of Lawrence Company Data}

The dataset for the Upper Weave Room of Lawrence Company Mill No. 2 was obtained from payroll records from 1833-1836 and 1838-1855 at the Baker Library Historical Collections at Harvard Business School. Lazonick and Brush [1985] originally collected most of this data and 
graciously shared it. To their data I added records for 1833 and provided some general cleaning. The resulting data include 15,945 monthly observations on 1,963 individuals. Each record includes name, days worked, earnings, piece rate (if on piece rate), pieces produced, signature (indicating literacy) and supplementary data including hours per day, total pieces produced, and yards per piece. The production of individual dayhands is not recorded, however, total production is recorded allowing the average productivity of dayhands to be calculated. I estimated an average rate for dayhands of 0.66 pieces per day over the entire sample with little evidence of any trend.

Productivity calculations assign dayhands this production rate. Alternate calculations show that the human capital estimates and productivity regressions are not particularly sensitive to this figure.

\section{Calculating Human Capital Investment}

The standard measure of human capital investment is obtained from foregone earnings or foregone output [Becker, 1993], depending on whether the investment is made by employee or employer. Given the high employee separation rate at Lowell, it is helpful to present a simple model of human capital that includes separations.

Index time periods by $t=0,1, \ldots$ The worker receives wages and the firm collects revenues at the end of each period. For simplicity, initially assume that all learning activity takes place the first period a worker is hired. During this period, a worker earns wage $w_{0}$ and produces output $y_{0}$. Subsequently, a fully trained worker, if still employed at the firm, earns $w_{T}$ and produces output $y_{T}$.

At the end of each period, there is a hazard $d$ that any worker will be fired or will quit. For simplicity, I initially assume this hazard is constant. Also, I assume that once a worker separates from the firm, she cannot use these learned skills elsewhere and returns to alternative employment at market wage $w .^{26}$

The worker's expected present value can be calculated as follows. At the end of the first period $(t=0)$, the worker's discounted earnings are $\frac{w_{0}}{1+r}$, assuming a constant discount rate of $r$.

For subsequent periods $(t>0)$, if the worker is still employed at the firm, with probability $(1-d)^{t}$, the worker's discounted earnings are $\frac{w_{T}}{(1+r)^{t+1}}$. On the other hand, with probability

\footnotetext{
26 In practice, the separation rate is adjusted to allow employees to work at other firms and to allow firms to hire previously trained workers. In effect, $d$ is the rate of employee separations from the local industry. It also may vary from month to month. The exposition is made simpler without these considerations.
} 
$d \cdot(1-d)^{t-1}$ the worker will separate from the firm beginning in the $t$ th period, earning a termination value in alternative employment of $\frac{w / r}{(1+r)^{t}}$. Putting all of these together, the worker's expected present value at the beginning of employment is

$$
\begin{aligned}
W & =\frac{w_{0}}{1+r}+\sum_{t=1}^{\infty} \frac{(1-d)^{t} w_{T}}{(1+r)^{t+1}}+\sum_{t=1}^{\infty} \frac{d \cdot(1-d)^{t-1} w / r}{(1+r)^{t}} \\
& =\frac{w_{T}+d \cdot w / r-(d+r) \cdot I_{w}}{d+r}, I_{w} \equiv \frac{w_{T}-w_{0}}{1+r}
\end{aligned}
$$

where $I_{w}$ is the value of discounted foregone earnings relative to the wage of a fully trained worker, $w_{T}$; as above, this equals the worker's human capital investment.

Now if labor markets are competitive, $W$ should equal the value of alternative work at the market wage. That is,

$$
W=\frac{w}{r}
$$

Solving this for $w_{T}$ yields

$$
w_{T}=w+(d+r) \cdot I_{w} .
$$

Following standard human capital analysis, the second term on the right is the return on human capital investment, and the worker's human capital investment is $I_{w}$. The separation rate, $d$, acts like the "depreciation" on human capital. Note also that a little algebra shows that

$$
I_{w}=\frac{w-w_{0}}{1-d}
$$

When $d=0$, the human capital investment takes the more familiar form of $w-w_{0}$, earnings foregone relative to alternative employment.

A similar process generates an expression for the firm's human capital investment.

Designate the output price as $p$ and the rental cost of capital per machine as $c$. During periods with new hires, the firm will earn profits per worker (before discounting) of $\pi_{0} \equiv p \cdot y_{0}-w_{0}-n \cdot c$. During periods with fully trained workers, profits will be $\pi_{T} \equiv p \cdot y_{T}-w_{T}-n \cdot c$. Since the firm replaces every worker who separates from the firm, the probability that a worker will be a new hire during any period after the first period is $d$ and the probability that the worker will be fully trained is $1-d$. The expected present value of a worker to the firm is then 


$$
\begin{aligned}
F & =\frac{\pi_{0}}{1+r}+\sum_{t=1}^{\infty} \frac{d \cdot \pi_{0}+(1-d) \cdot \pi_{T}}{(1+r)^{t+1}} \\
& =\frac{\pi_{T}-(d+r) \cdot I_{f}}{r}, \quad I_{f} \equiv \frac{\pi_{T}-\pi_{0}}{1+r}
\end{aligned}
$$

where, as above, $I_{f}$ is the firm's discounted foregone profit. Assuming that the firm is in equilibrium regarding its investment activities, $F$ will equal the present value of profits the firm could earn in other activities, $F=\pi / r$. So, considering (A5),

$$
\pi_{T}=\pi+(d+r) \cdot I_{f} .
$$

The term $(d+r) \cdot I_{f}$ represents the rent on the firm's human capital investment including "depreciation". $\pi$ is the alternative profit stream, but in a steady state equilibrium, where the firm replaces all workers who leave, steady state profits, $\bar{\pi}$, must equal $\pi$ :

$$
\bar{\pi}=\pi_{T}-(d+r) \cdot I_{f}=p \cdot y_{T}-w_{T}-n \cdot c-(d+r) \cdot I_{f} .
$$

The total human capital investment can be calculated

$$
I \equiv I_{w}+I_{f}=\frac{p \cdot\left(y_{T}-y_{0}\right)}{1+r}
$$

just the discounted value of foregone output. Note that inserting (A3) and (A7) into (A6) yields a useful alternative expression

$$
\bar{\pi}=p \cdot y_{T}-w-n \cdot c-(d+r) \cdot I .
$$

This simple model of one period learning can be extended to learning over multiple periods. I calculated two different versions of human capital investment over multiple periods.

First, suppose a worker takes $T$ periods to complete training and the worker produces $y_{t}$ and earns $w_{t}$ in each period prior to $T, t=0,1, \ldots T-1$. Then the investments in a worker who completes training are (by similar process)

$$
I^{*}=\sum_{i=0}^{T-1} \frac{p \cdot\left(y_{T}-y_{i}\right)}{(1+r)^{i+1}}, \text { and } \quad I_{w}^{*}=\sum_{i=0}^{T-1} \frac{\left(w_{T}-w_{i}\right)}{(1+r)^{i+1}} .
$$

Note that this is the investment in a worker, conditional on that worker completing training.

With multi-period learning, however, workers may quit or be fired before completing training. In fact, separation rates were greatest during the first three months at Lowell. To obtain one fully trained worker, the firm had to hire more than one worker on average. Also, workers will take into account the possibility that they may not complete training. Suppose that separation rates vary for each period during training, the set of rates being $\left\{d_{0}, d_{1}, \ldots, d_{T}\right\}$, designating the 
separation rate after training as $d_{T}$. Then this situation may be modeled as a discrete Markov chain. Workers with different amounts of training are in different "states," indexed by the number of months of training, $s, 0 \leq s \leq T$. The probability that a worker has had $s$ months of training is the state variable and a transition matrix can be constructed from the $d_{i}$. By repeatedly applying the transition matrix to an initial state vector $\{1,0,0 \ldots\}$, I calculated the present value of the profit stream of a worker, $\hat{F}$. Then, assuming $\hat{F}=\pi / r$, and using (A8),

$$
\hat{I}=\frac{p \cdot y_{T}-w-n \cdot c-r \cdot \hat{F}}{d_{T}+r} .
$$

A similar procedure yields numeric estimates for the worker's investment, $\hat{I}_{w}$.

This second measure of human capital investment requires more information and is more complex to calculate than the first measure. It may be larger or smaller than the first measure, however, for the separation patterns at the Lawrence Company (with a declining proportional hazard), the second measure turns out to be substantially larger. In general, if one assumes a significantly declining hazard, then the first measure can be considered a lower bound estimate of total human capital investment.

\section{References}

Acemoglu, Daron and Jörn-Steffen Pischke (1999), "Beyond Becker: Training in Imperfect Labor Markets," The Economic Journal. v. 109, p. F112-F142.

Allen, Z. (1832), The Practical Tourist. in G. Kulik, R. Parks, and T. Penn (eds, 1982), The New England Mill Village 1790-1860, Cambridge, MA: MIT Press.

Allen, Z. (1861), Historical, Theoretical, and Practical Account of Cotton Manufacture. in G. Kulik, R. Parks, and T. Penn (eds, 1982), The New England Mill Village 1790-1860, Cambridge, MA: MIT Press.

Appleton, N. (1858), Introduction of the Power Loom and Origin of Lowell. Lowell, MA: Penhallow.

Argote, L. and Epple, D. (1990), 'Learning Curves in Manufacturing.' Science. 920.

Arrow, K. (1962), 'The Economic Implications of Learning by Doing.' Review of Economic Studies. 155.

Auerswald, P., Kauffman, S., Lobo, J. and Shell, K (2000), 'The Production Recipes Approach to Modeling Technological Innovation: An Application to Learning by Doing.' Journal of Economic Dynamics and Control 24, 389-450.

Batchelder, S. (1863), Introduction and Early Progress of the Cotton Manufacture in the United States. (reprinted 1972), Clifton, NJ: Kelley.

Becker, G. (1993), Human capital; a theoretical and empirical analysis, with special reference to education. Third Edition, Chicago: University of Chicago Press. 
Belsey, D., E. Kuh and R. Welsch (1980), Regression Diagnostics: Identifying Influential Data and Sources of Collinearity, New York: John Wiley and Sons.

Bernard, Richard M. and Maris A. Vinovskis, (1977), "The Female School Teacher in AnteBellum Massachusetts," Journal of Social History, v. 10, p. 332-345.

Boot, H. M. (1995), 'How Skilled were Lancashire Cotton Factory Workers in 1833?.' Economic History Review 48, 283-303.

Braverman, H. (1974), Labor and Monopoly Capital. New York and London: Monthly Review Press.

British Parliamentary Papers.

Brito, D. and Williamson, J. (1973), 'Skilled Labor and Nineteenth Century Anglo-American Managerial Behavior.' Explorations in Economic History 10, 235-51.

Bryan, W. and Harter, N. (1897), 'Studies in the Psychology and Physiology of the Telegraphic Language.' Psychology Review 4, 27.

Bryan, W. and Harter, N. (1899), Psychology Review 6, 345.

Catling, H. (1970), The Spinning Mule. London: Newton, Abbot, David and Charles.

Chao, K. (1977), The Development of Cotton Textile Production in China. Cambridge, Mass. And London: Harvard University Press.

Clark, G. (1987), 'Why Isn't the Whole World Developed? Lessons from the Cotton Mills.' Journal of Economic History 47, 141-173.

Copeland, M. (1912), The Cotton Manufacturing Industry of the United States. Cambridge, Mass.: Harvard University.

Crafts, N. F. R. (1995), "Exogenous of Endogenous Growth? The Industrial Revolution Reconsidered," Journal of Economic History 55, 745-772.

David, P. (1975), Technical Choice, Innovation and Economic Growth. Cambridge University Press, Chaps. 2 and 3.

Davis, L. and Stettler, L. (1966), 'The New England Textile Industry 1825-1860.' in NBER, Output, Employment, and Productivity in the United States after 1800, New York: Columbia University Press.

Dublin, T. (1993), Women at Work: The Transformation of Work and Community in Lowell, Massachusetts, 1826-1860, $2^{\text {nd }}$ edition. New York: Columbia University Press.

Elbaum, B. (1989), 'Why Apprenticeship Persisted in Britain But Not in the United States.' Journal of Economic History 49, 337-349.

Elbaum, B. and Singh, N. (1995), 'The Economic Rationale of Apprenticeship Training: Some Lessons from British and U.S. Experience.' Industrial Relations 34, 593-622.

Ford, H. (1923), My Life and Work. Garden City, NY: Doubleday. 129-130.

Gersuny, Carl. (1976) “ 'A Devil in Petticoats' and Just Cause: Patterns of Punishment in Two New England Textile Factories," Business History Review, L, p. 131-152.

Gibb, G. (1950), The Saco-Lowell Shops: Textile machinery building in New England 18131949. New York: Russell \& Russell.

Goldin, Claudia and Kenneth Sokoloff (1984), "The Relative Productivity Hypothesis of Industrialization: the American case," Quarterly Journal of Economics, v. 99, p. 461-88. 
Goldstone, J. (1996), 'Gender, Work, and Culture: Why the Industrial Revolution cam Early to England but Late to China.' Sociological Perspectives 39, 1-21.

Habakkuk, H. (1962), American and British Technology in the Nineteenth Century. Cambridge, UK: Cambridge University Press.

Harley, C. K. (1974), 'Skilled Labor and the Choice of Technique in Edwardian Industry.' Explorations in Economic History 11, 391-414.

Harvard Business School, Baker Library Historical Collections, Records of the Hamilton Manufacturing Company.

Harvard Business School, Baker Library Historical Collections, Records of the Lawrence Company.

Hashimoto, M. (1981), 'Firm-Specific Human Capital as a Shared Investment.' American Economic Review 71, 475-482.

Josephson, H. (1949), Golden Threads; New England Mill Girls and Magnates. New York: Russell \& Russell.

Jovanovic, B. and Nyarko, Y. (1995), 'A Bayesian learning model fitted to a variety of empirical learning curves.' Brookings Papers: Microeconomics. 247.

Kulik, G., Parks, R. and Penn, T. (eds) (1982), The New England Mill Village 1790-1860. Cambridge, MA: MIT Press.

Landes, D. (1969), The Unbound Prometheus. Cambridge University Press.

Lazonick, W. and Brush, T. (1985), 'The 'Horndal Effect' in Early U. S. Manufacturing.' Explorations in Economic History 22, 53-96.

Lyons, J. (1987), 'Powerloom Profitability and Steam Power Costs: Britain in the 1830s.' Explorations in Economic History 34, 392-408.

Marglin, S. (1974), 'What Do Bosses Do?' Review of Radical Political Economy 6, 60-112.

Margo, Robert A. (2000), Wages \& Labor Markets in the United States, 1820-1860. Chicago: University of Chicago Press.

McGouldrick, P. (1968), New England Textiles in the Nineteenth Century. Cambridge, Mass.: Harvard University Press.

Miles, H. A. (1845), Lowell as it Was, and as it Is. (reprinted 1972) New York: Arno Press.

Mitch, D. (1992), The Rise of Popular Literacy in Victorian England. Philadelphia: University of Pennsylvania Press.

Mitch, D. (1999), 'The Role of Education and Skill in the British Industrial Revolution.' in J. Mokyr, The British Industrial Revolution: An Economic Perspective. Boulder, CO: Westview Press.

Montgomery, J. (1840), Cotton Manufacture. in D. Jeremy, Technology and Power in the Early American Cotton Industry, (1990), Philadelphia: American Philosophical Society.

More, C. (1980), Skill and the English Working Class, 1870-1914. New York: St. Martins Press.

Muth, J. (1986), 'Search Theory and the Manufacturing Progress Function.' Management Science. 948.

Nickless, P. (1979), 'A New Look at Productivity in the New England Cotton Textile Industry, 1830-1860.' Journal of Economic History 39, 889-907. 
31 - Skills of the Unskilled - February, 2002

Perlman, J. and Shirley, D. (1991), 'When Did New England Women Acquire Literacy?.' William and Mary Quarterly 46, 50-67.

Rosenberg, N. (1967), 'Anglo-American Wage Differences in the 1820's.' Journal of Economic History 27, 221-29.

Saxonhouse, G. (1977), 'Productivity Change and Labor Absorption in Japanese Cotton Spinning, 1891-1935.' Quarterly Journal of Economics 91, 195-219.

Saxonhouse, G. and Wright, G. (1984), 'Two forms of Cheap Labor in Textile History.' In Saxonhouse and Wright (eds.), Technique, Spirit and Form in the Making of the Modern Economies: Essays in Honor of William N. Parker. Research in Economic History Supp. 3, 3-31.

Shlakman, V. (1935), Economic history of a factory town; a study of Chicopee, Massachusetts. (reprinted 1969) New York: Octagon Books.

Sokoloff, Kenneth (1984), "Was the Transition from the Artisanal Shop to the Nonmechanized Factory Associated with Gains in Efficiency? Evidence from the U.S. Manufacturing Censuses of 1820 and 1850," Explorations in Economic History, v. 21, p. 351-382.

Smith, Adam (1776), An Inquiry into the Nature and Causes of the Wealth of Nations.

Thompson, E. P. (1964), The Making of the English Working Class. London.

Tucker, Barbara M. (1984), Samuel Slater and the Origins of the American Textile Industry, 1790-1860. Ithaca and London: Cornell University Press.

Ure, A. (1836), The Cotton Manufacture of Great Britain. London: Knight.

U. S. Bureau of the Census (1975), Historical Statistics of the United States from Colonial Times to 1970. Washington, DC: Government Printing Office.

Valverde, M. (1988), 'Giving the Female a Domestic Turn': the social, legal and moral regulation of women's work in British cotton mills, 1820-1850.' Journal of Social History 21, 619-634.

von Tunzelman, G. N. (1978), Steam Power and British Industrialization to 1860. Oxford: Clarendon Press.

Ware, C. (1931), The Early New England Cotton Manufacture. Boston and New York: Houghton Mifflin.

Williamson, J. (1972), 'Embodiment, Disembodiment, Learning by Doing and Constant Returns to Scale in the Nineteenth Century Cotton Textiles.' Journal of Economic History 32, 699-705.

Williamson, J. and Lindert, P. (1980), American Inequality: a Macroeconomic History. New York: Academic Press.

Wright, G. (1986), Old South, New South. New York: Basic Books, Chap. 5.

Wright, T. (1936), Journal of Aeronautical Science. 122.

Zevin, R. (1971), 'The Growth of Cotton Textile Production After 1815.' in R. Fogel and S. Engerman, The Reinterpretation of American Economic History, New York: Harper \& Row, 122-147.

Zevin, R. (1975), The Growth of Manufacturing in Early Nineteenth Century New England. New York: Arno. 


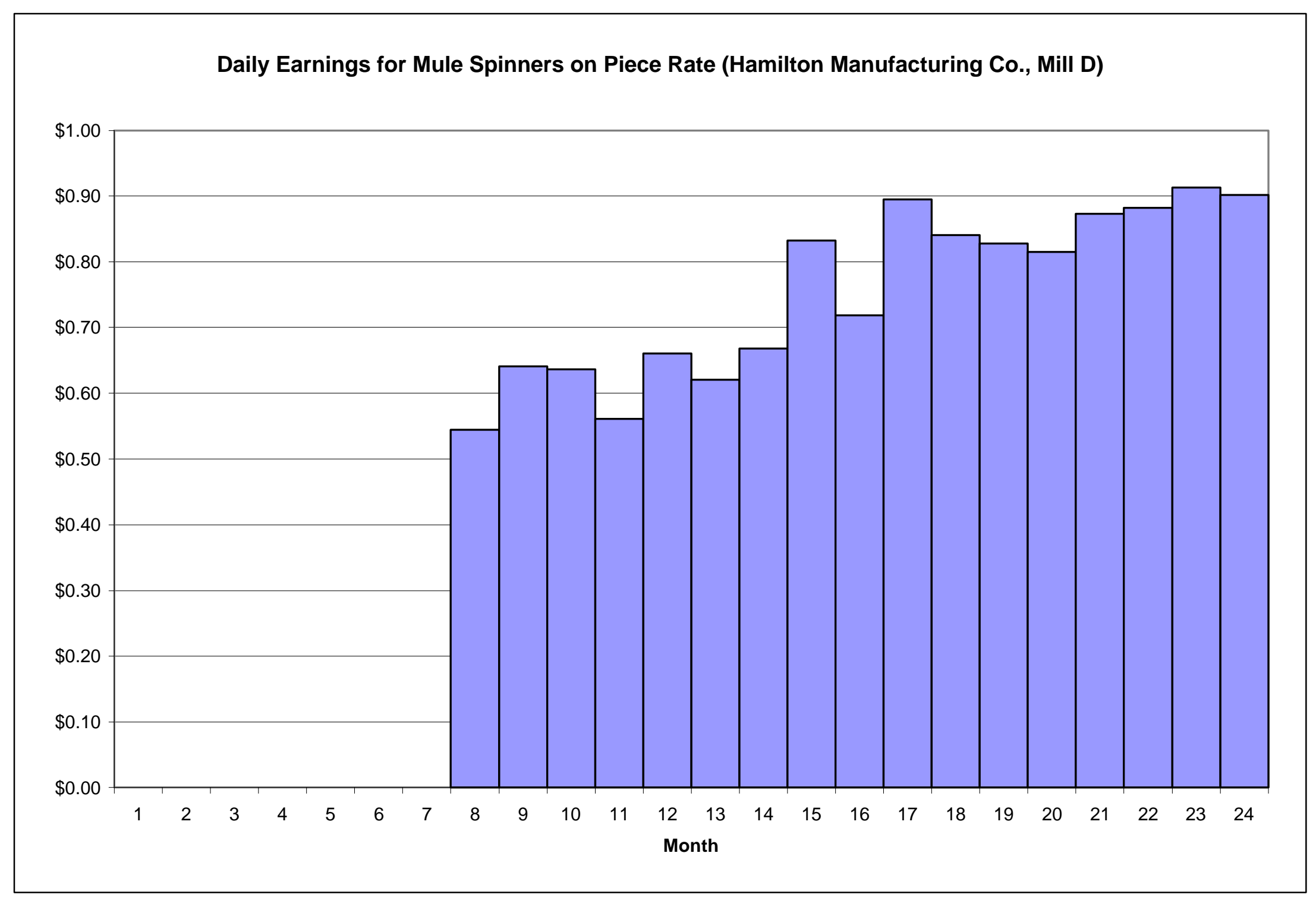

Figure 1. Learning Curve for Hamilton Company Mill D Mule Spinning Jobhands.

Piece rate earnings for payrolls starting June, 1847. Jobhands earned different piece rates for different yarns produced. 
Yard per Hour for Weavers, Lawrence Co.

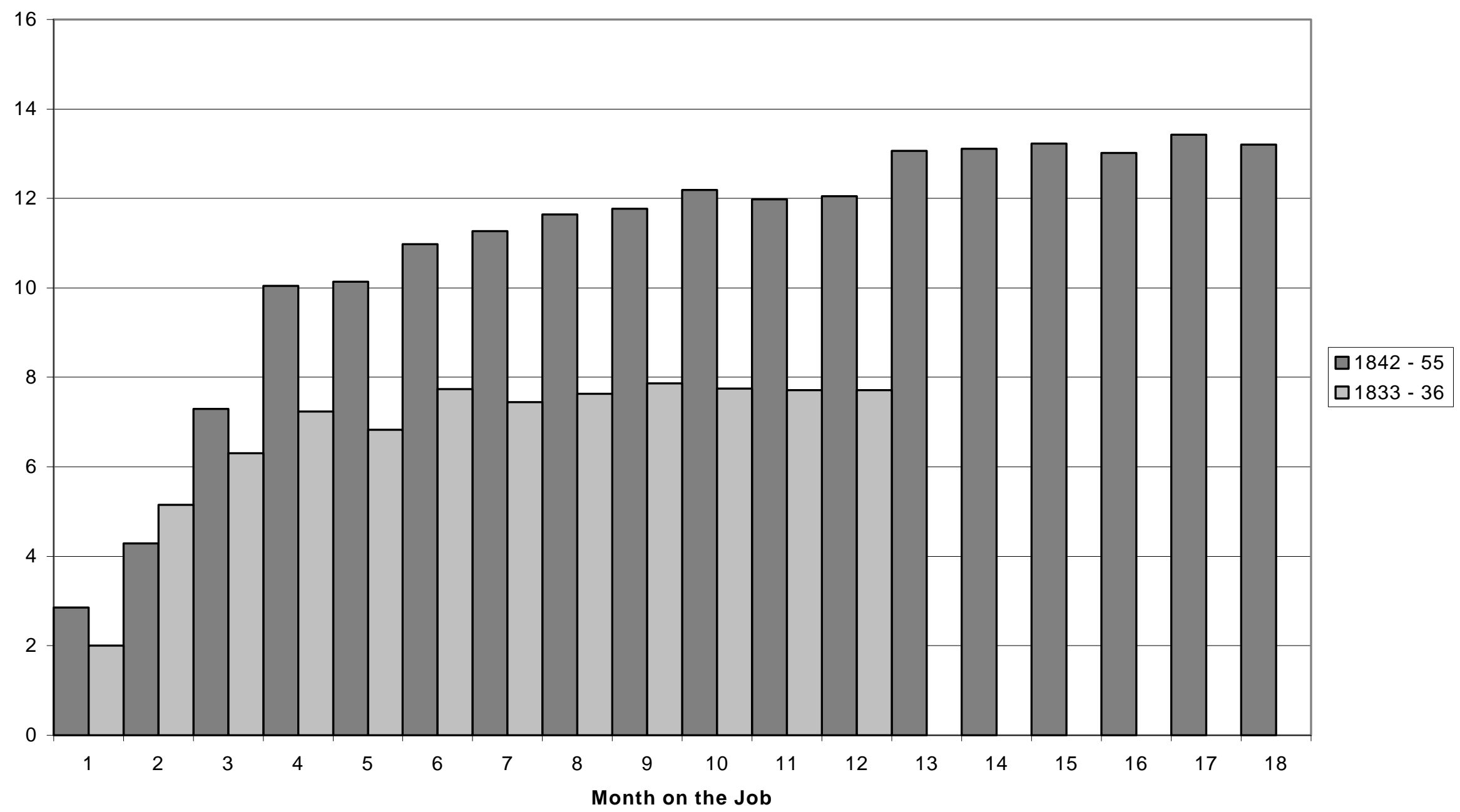

Figure 2. Learning Curve for Loom Tenders in Lawrence Company, Mill No. 2, Upper Weave Room, 1833-36 and 1842-55

Note: Means for balanced panel of 50 (1833-36) and 30 (1842-55) workers who entered the Upper Weaving Room, who worked for at least 12 (or 18) months in this Room. This sample excludes workers who spent no time on day rate (previously experienced) and workers who spend 72 days or more on day rate (permanent dayhands). In calculating yards per hour, workers on day rate were allocated the average productivity of all workers on day rate. 
Figure 3. Worker Human Capital Calculation

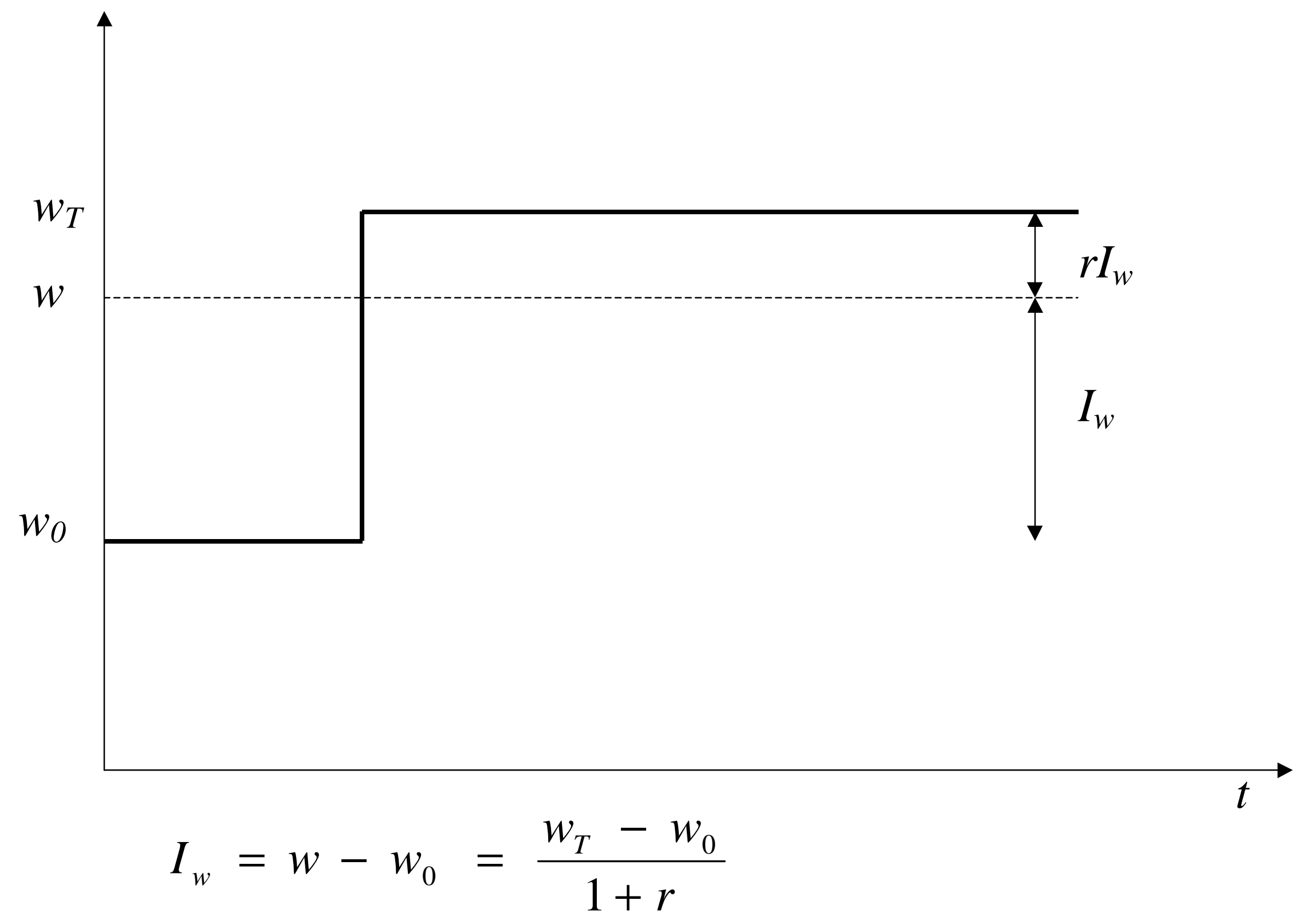

34 - The Skills of the Unskilled 


\section{Characteristics of New Hires}

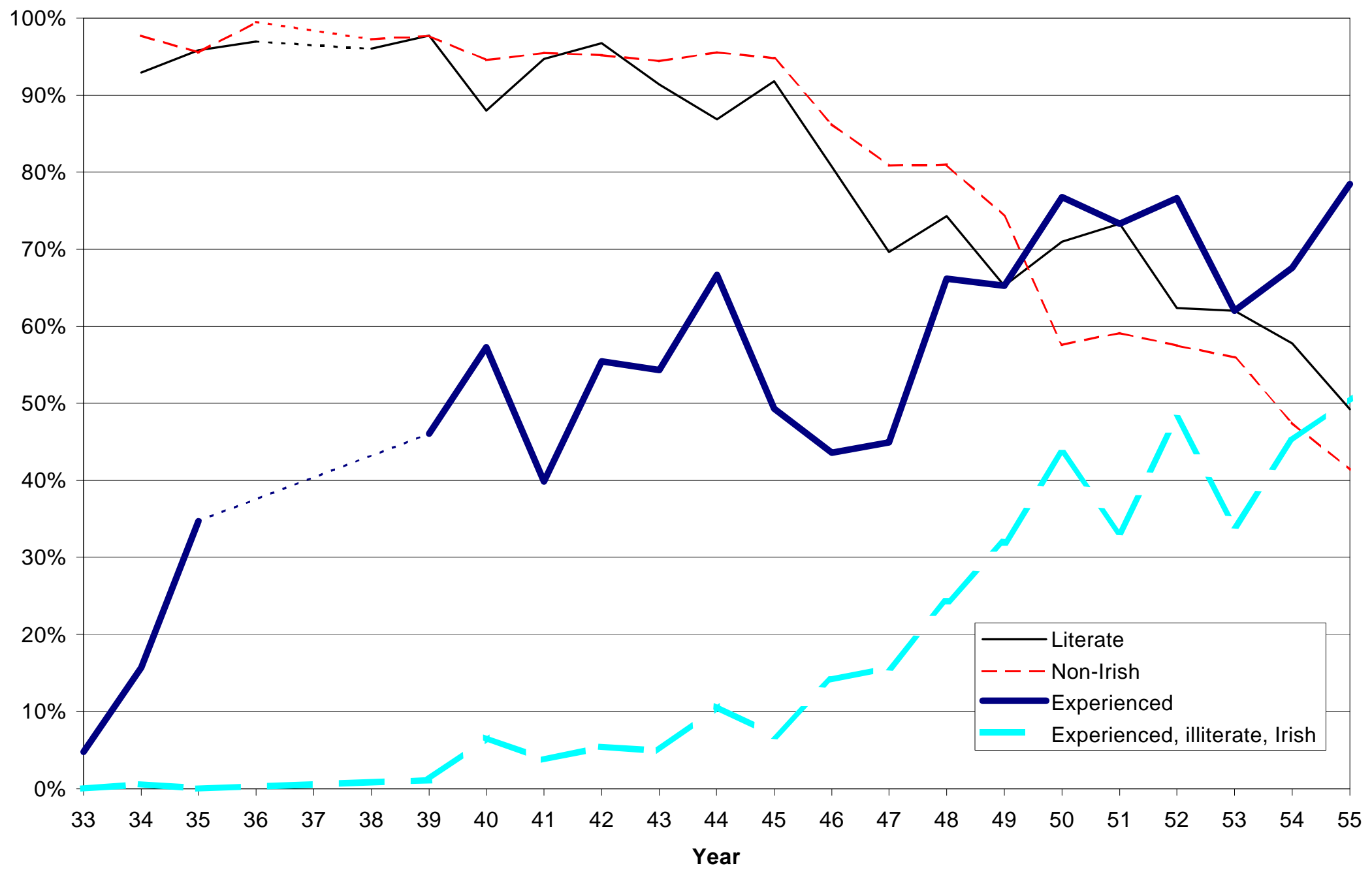

Figure 4. Characteristics of New Hires: Previous Experience, Literacy and Ethnicity, Lawrence Company, Mill No. 2 Upper Weave Room, 1834-55

New hires who did not work dayrate their first month are assumed to have previous experience. Literacy is determined by ability to sign payroll register. Ethnicity is determined by surname. See Lazonick and Brush [1985] for details. Excludes overseers and overseer's assistants. 


\section{Table 1. Human Capital Investment Calculations}

\begin{tabular}{|c|c|c|c|c|}
\hline & & Lawrence & Weavers & Hamilton Co. \\
\hline & & $1833-36$ & $1842-55$ & \\
\hline Mean number of days on day rate & & 24.7 & 32.6 & $\sim 156$ \\
\hline Total learning period (months) & $\bar{x}$ & 6 & 11 & 16 \\
\hline Estimated physical capital / piecehand & & $\$ 358$ & $\$ 497$ & $\$ 1,546$ \\
\hline Calculations assuming no separations $d$ & trai & & & \\
\hline Foregone output (yards) & $C$ & 2,783 & 10,502 & \\
\hline Total human capital investment per worker & $I$ & $\$ 32.56$ & $\$ 94.54$ & $\$ 314.16$ \\
\hline Worker's human capital investment & $I_{w}$ & $\$ 6.42$ & $\$ 23.31$ & $\$ 109.46$ \\
\hline Total human capital / annual earnings & & $22 \%$ & $61 \%$ & $113 \%$ \\
\hline Workers' share of investment & & $20 \%$ & $25 \%$ & $35 \%$ \\
\hline Calculations allowing separations during & ing & & & \\
\hline Total human capital investment per worker & $\hat{I}$ & $\$ 47.39$ & $\$ 161.62$ & -- \\
\hline Worker's human capital investment & $\hat{I}_{w}$ & $\$ 9.03$ & $\$ 32.39$ & -- \\
\hline Total human capital / annual earnings & & $32 \%$ & $104 \%$ & -- \\
\hline Workers' share of investment & & $19 \%$ & $20 \%$ & -- \\
\hline
\end{tabular}

Note: Physical capital estimates based on data from Montgomery [1840] and Hamilton Company inventory. I assume an annual discount rate of $5 \%$. I calculated the value of output by compiling average cost (including wages and salaries, general and administrative costs, and capital depreciation, but excluding cotton costs and interest on capital) and applying a markup of $16.5 \%$ (the mean for 6 Lowell companies for the years 1836-55 calculated by McGouldrick [1968, Table 47]). Overhead costs were derived from Montgomery [1840]. For the Lawrence Company, estimates are based on a sample of workers who worked at least 7 months (1833-36) or 11 months (1842-55) without interruption, and who spent some days on dayrate but fewer than 72 days on dayrate. The sample sizes were 111 (1833-36) and 72 (1842-55). Since the length of each month varied, monthly observations of output and wages are calculated by multiplying hourly output and wage rates by average hours per month for the sample. For the Hamilton mule spinners, the sample consisted of a single cohort. The Hamilton estimates were derived using a slightly different, but equivalent procedure because of data limitations. Human capital calculations are described in the text. Total human capital / annual earnings is the ratio of total human capital investment to annual earning of a fully trained worker. Workers' share of investment is the ratio of worker's human capital investment to total human capital investment. 
Table 2. Individual Production Functions

Dependent variable: Log of yards per hour for each worker each month (Column 5: Fixed Effects from Column 2)

\begin{tabular}{|c|c|c|c|c|c|}
\hline & 1 & 2 & 3 & 4 & 5 \\
\hline & ML & ML & ML & ML & OLS \\
\hline $\begin{array}{l}\text { Log looms per worker } \\
(\ln n)\end{array}$ & $\begin{array}{l}-.138 \\
(.049)\end{array}$ & $\begin{array}{l}-.258 \\
(.046)\end{array}$ & $\begin{array}{l}-.269 \\
(.049)\end{array}$ & $\begin{array}{l}-.117 \\
(.055)\end{array}$ & -- \\
\hline$b_{k}$ & $\begin{array}{l}57.84 \\
(3.67)\end{array}$ & $\begin{array}{l}47.76 \\
(2.63)\end{array}$ & $\begin{array}{l}44.11 \\
(2.70)\end{array}$ & $\begin{array}{l}49.89 \\
(3.19)\end{array}$ & -- \\
\hline$\alpha$ & $\begin{array}{l}1.55 \\
(.06)\end{array}$ & $\begin{array}{l}1.71 \\
(.07)\end{array}$ & $\begin{array}{l}1.69 \\
(.06)\end{array}$ & $\begin{array}{l}1.58 \\
(.06)\end{array}$ & -- \\
\hline $\begin{array}{l}\text { Log effective experience } \\
(\ln z)\end{array}$ & $\begin{array}{l}.586 \\
(.006)\end{array}$ & $\begin{array}{l}.611 \\
(.006)\end{array}$ & $\begin{array}{l}.589 \\
(.006)\end{array}$ & $\begin{array}{l}.584 \\
(.006)\end{array}$ & -- \\
\hline Year (trend) & $\begin{array}{l}.002 \\
(.001)\end{array}$ & $\begin{array}{l}-.008 \\
(.003)\end{array}$ & $\begin{array}{l}.005 \\
(.001)\end{array}$ & & -- \\
\hline Year dummy variables & & & & $\checkmark$ & $\checkmark$ \\
\hline$\frac{\text { Individual Characteristics }}{\text { Literate }}$ & & & $\begin{array}{l}.170 \\
(.011)\end{array}$ & $\begin{array}{l}.182 \\
(.011)\end{array}$ & $\begin{array}{l}.127 \\
(.031)\end{array}$ \\
\hline Non-Irish & & & $\begin{array}{l}.079 \\
(.013)\end{array}$ & $\begin{array}{l}.109 \\
(.013)\end{array}$ & $\begin{array}{l}.089 \\
(.040)\end{array}$ \\
\hline Previously Experienced & & & $\begin{array}{l}.114 \\
(.016)\end{array}$ & $\begin{array}{l}.128 \\
(.016)\end{array}$ & $\begin{array}{l}.008 \\
(.015)\end{array}$ \\
\hline Employment gaps & & & $\begin{array}{l}.033 \\
(.008)\end{array}$ & $\begin{array}{l}.039 \\
(.008)\end{array}$ & $\begin{array}{l}.017 \\
(.021)\end{array}$ \\
\hline Individual Fixed Effects & & $\checkmark$ & & & \\
\hline Constant & $\begin{array}{l}-.834 \\
(.038)\end{array}$ & & $\begin{array}{r}-1.022 \\
(.039)\end{array}$ & & \\
\hline$R^{2}$ & .58 & .80 & .59 & .60 & .12 \\
\hline
\end{tabular}

Note: Number of observations is 14,306 (1,386 for col. 5). This excludes workers who appear in the payroll records for only one month, months of known water power shortages and observations of experienced workers on dayrate. Asymptotic standard errors in parentheses. For OLS estimation, standard errors are heteroscedastic-consistent. The number of looms per worker is the average for the Upper Weaving Room. Effective experience is $\min (x, \bar{x})$ where $x$ is the number of days worked. $\bar{x}=b_{k} \cdot n^{\alpha}$. The OLS estimation uses fixed effects from Column 2 as dependent variable. Literacy was judged by ability to sign name in payroll register. Probability of Irish background was assigned based on surname [see Lazonick and Brush, 1985]. Workers who did not work on day rate their first month were assumed to have previous experience. The employment gap dummy is 1 if the worker's name was missing from the payroll register for the Upper Weaving Room for one or more months, but reappeared subsequently. 


\section{Table 3. Pro-Forma Calculations of Hourly Profit}

\section{Number of looms / worker}

Price / yard for weaving (cents)

Output rate (yards / loom-hour)

Revenue / worker-hour (cents)

Rental cost per loom (cents / hour)

Capital hourly rental cost (cents)

Adjusted hourly wage (cents)

Local monthly separation rate

Retention rate

Permanent separation rate

Foregone output (yards)

Human capital / fully-trained worker

Hourly depreciation / worker (cents)

\section{Net profit / worker (cents / hour)}

\section{Net profit / loom (cents / hour)}

\begin{tabular}{|c|c|c|c|c|}
\hline \multirow[b]{2}{*}{$n$} & \multicolumn{2}{|c|}{1834} & \multicolumn{2}{|c|}{1842} \\
\hline & 2 & 3 & 2 & 3 \\
\hline \multirow[t]{3}{*}{$p$} & 1.21 & 1.21 & 1.02 & 1.02 \\
\hline & 3.93 & 3.83 & 3.93 & 3.83 \\
\hline & 9.5 & 13.9 & 8.0 & 11.7 \\
\hline \multirow[t]{2}{*}{$c$} & 1.5 & 1.5 & 1.5 & 1.5 \\
\hline & 3.0 & 4.5 & 3.0 & 4.5 \\
\hline \multirow[t]{3}{*}{$w$} & 4.3 & 4.3 & 4.5 & 4.5 \\
\hline & $14.6 \%$ & $14.6 \%$ & $11.6 \%$ & $11.6 \%$ \\
\hline & $16 \%$ & $16 \%$ & $48 \%$ & $48 \%$ \\
\hline$d$ & $12 \%$ & $12 \%$ & $6 \%$ & $6 \%$ \\
\hline$C$ & 2,783 & 10,502 & 2,783 & 10,502 \\
\hline$p C$ & $\$ 33.67$ & $\$ 127.07$ & $\$ 28.39$ & $\$ 107.12$ \\
\hline$d p C$ & 1.3 & 5.1 & 0.6 & 2.1 \\
\hline \multirow[t]{2}{*}{$\pi$} & 0.8 & 0.0 & -0.1 & 0.6 \\
\hline & 0.4 & 0.0 & 0.0 & 0.2 \\
\hline
\end{tabular}

Note: Values in cents per hour. The price per yard for weaving is based on realized cost per yard marked up 16.5\% (from McGouldrick, 1968). The outputs per loom hour are the values for the fully trained workers in the samples used to calculate human capital investments. Capital rental costs are derived from

Montgomery's data and include depreciation, insurance, interest at 5\% and overhead costs. Although workers were paid by the piece, I use hourly earnings for fully trained workers, adjusted (see Appendix) by subtracting the worker's share of human capital rent (20\%). Retention rates are determined as the ratio of new hires with experience to separations. Permanent separation rate is local separation rate time one minus the retention rate. 


\section{Table 4. Pro-Forma Calculations of Hourly Profit with Literacy}

\section{Number of looms / worker}

Price / yard for weaving (cents)

Output rate (yards / loom-hour)

Revenue / worker-hour (cents)

Rental cost per loom (cents / hour)

Capital hourly rental cost (cents)

Adjusted hourly wage (cents)

\begin{tabular}{|c|c|c|c|c|c|c|c|c|}
\hline \multirow[b]{2}{*}{$n$} & \multicolumn{2}{|c|}{1834} & \multicolumn{2}{|c|}{1842} & \multicolumn{4}{|c|}{1854} \\
\hline & $\begin{array}{l}\text { Literate } \\
\quad 2\end{array}$ & $\begin{array}{c}\text { Illiterate } \\
\mathbf{2}\end{array}$ & $\begin{array}{l}\text { Literate } \\
\quad \mathbf{3}\end{array}$ & $\begin{array}{c}\text { Illiterate } \\
\mathbf{3}\end{array}$ & $\begin{array}{l}\text { Literate } \\
\quad 3\end{array}$ & $\begin{array}{c}\text { Illiterate } \\
\mathbf{3}\end{array}$ & $\begin{array}{l}\text { Literate } \\
\quad \mathbf{4}\end{array}$ & $\begin{array}{c}\text { Illiterate } \\
\mathbf{4}\end{array}$ \\
\hline \multirow[t]{2}{*}{$p$} & 1.21 & 1.21 & 1.02 & 1.02 & 0.90 & 0.90 & 0.90 & 0.90 \\
\hline & 3.93 & 3.51 & 3.83 & 3.42 & 3.83 & 3.42 & 3.83 & 3.42 \\
\hline & 9.5 & 8.5 & 11.7 & 10.5 & 10.3 & 9.2 & 13.7 & 12.3 \\
\hline \multirow[t]{2}{*}{$c$} & 1.5 & 1.5 & 1.5 & 1.5 & 1.5 & 1.5 & 1.5 & 1.5 \\
\hline & 3.0 & 3.0 & 4.5 & 4.5 & 4.5 & 4.5 & 6.0 & 6.0 \\
\hline$w$ & 4.4 & 3.9 & 4.5 & 4.0 & 4.5 & 4.0 & 4.5 & 4.0 \\
\hline
\end{tabular}

Monthly local separation rate

Retention rate

Permanent separation rate

Foregone output (yards)

Human capital / fully-trained worker

Hourly depreciation / worker (cents)

\section{Net profit / worker-hour (cents)}

\section{Net profit / loom-hour (cents)}

\begin{tabular}{|c|c|c|c|c|c|c|c|c|}
\hline \multirow[t]{3}{*}{$w$} & 4.4 & 3.9 & 4.5 & 4.0 & 4.5 & 4.0 & 4.5 & 4.0 \\
\hline & $12.4 \%$ & $19.1 \%$ & $11.8 \%$ & $10.1 \%$ & $14.0 \%$ & $8.6 \%$ & $14.0 \%$ & $8.6 \%$ \\
\hline & $16 \%$ & $16 \%$ & $48 \%$ & $48 \%$ & $68 \%$ & $68 \%$ & $68 \%$ & $68 \%$ \\
\hline$d$ & $10 \%$ & $16 \%$ & $6 \%$ & $5 \%$ & $4 \%$ & $3 \%$ & $4 \%$ & $3 \%$ \\
\hline$C$ & 2,783 & 2,783 & 10,502 & 10,502 & 10,502 & 10,502 & 24,483 & 24,483 \\
\hline$p C$ & $\$ 33.67$ & $\$ 33.67$ & $\$ 107.12$ & $\$ 107.12$ & $\$ 94.20$ & $\$ 94.20$ & $\$ 219.61$ & $\$ 219.61$ \\
\hline$d p C$ & 1.1 & 1.8 & 2.1 & 1.8 & 1.4 & 0.8 & 3.2 & 2.0 \\
\hline \multirow[t]{2}{*}{$\pi$} & 1.0 & -0.2 & 0.5 & 0.1 & -0.1 & -0.2 & 0.0 & 0.3 \\
\hline & 0.5 & -0.1 & 0.2 & 0.0 & 0.0 & -0.1 & 0.0 & 0.1 \\
\hline
\end{tabular}

Note: Values in cents per hour. The price per yard for weaving is based on realized cost per yard marked up 16.5\% (from McGouldrick, 1968). The outputs per loom hour are the values for the fully trained workers in the samples used to calculate human capital investments. Capital rental costs are derived from Montgomery's data and include depreciation, insurance, interest at 5\% and overhead costs. Although workers were paid by the piece, I use hourly earnings for fully trained workers, adjusted (see Appendix) by subtracting the worker's share of human capital rent (20\%). Literate workers are assumed to be $12 \%$ more productive and to earn $12 \%$ more than illiterate workers. Mill separation rates are means for each period for each type of worker. Retention rates are determined as the ratio of new hires with experience to separations. Permanent separation rate is local separation rate time one minus the retention rate. 
Table 5. Pro-Forma Calculations of Cost per Yard in 1818

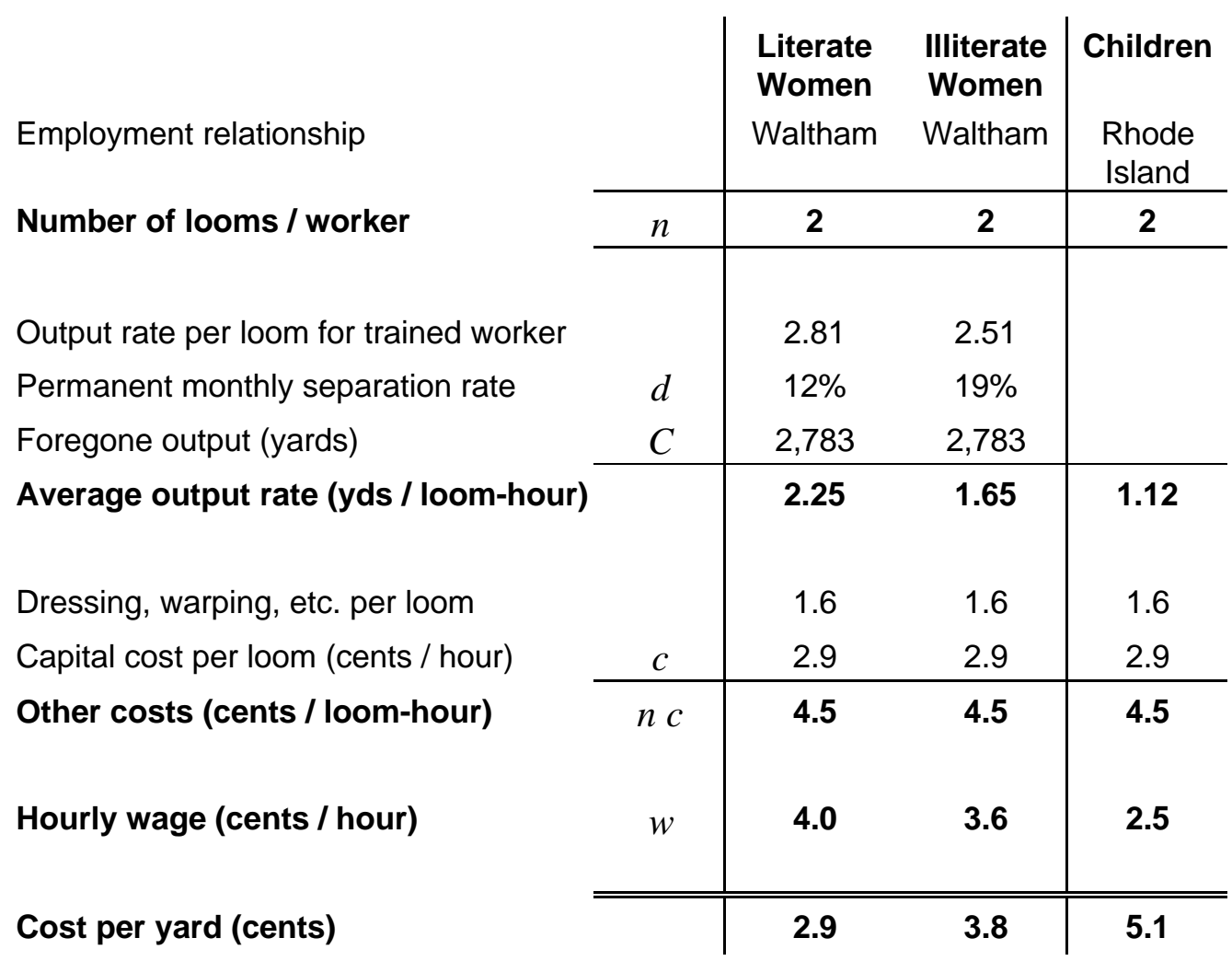

Note: This table represents the total cost per yard for warping, dressing and weaving a coarse shirting in 1818 and is extrapolated from data for 1834 used in Table 4. The output rate for a trained worker uses the value in Table 4, but assumes a loom rate of 100 picks per minute as opposed to 140 [Allen, 1861, Montgomery, 1840]. The average output per loom-hour is calculated by subtracting the prorated foregone output ( $\mathrm{d} n \mathrm{C}$ / hours per month). Variable costs for dressing, warping, etc. come from Montgomery, allowing for a $15 \%$ increase in wages to 1834 [Zevin, 1971]. Capital costs for dressing and weaving are also based on quantities from Montgomery, but equipment was valued at the prices charged by the Boston Manufacturing Company in 1817 [Gibb, 1950]. Building and other capital costs were adjusted relative to 1834 by McGouldrick's index for these figures (for 1827) [McGouldrick, 1968, Appendix C]. Wages were taken to be 15\% lower in 1818 [Zevin, 1971]. I assume output and wages for illiterate women are $12 \%$ less than for literate women as in Table 4. Children's wages were taken from the wages of boys, 11 or 12 years old in Allen [1832]. Average output for children is hypothetical. 